
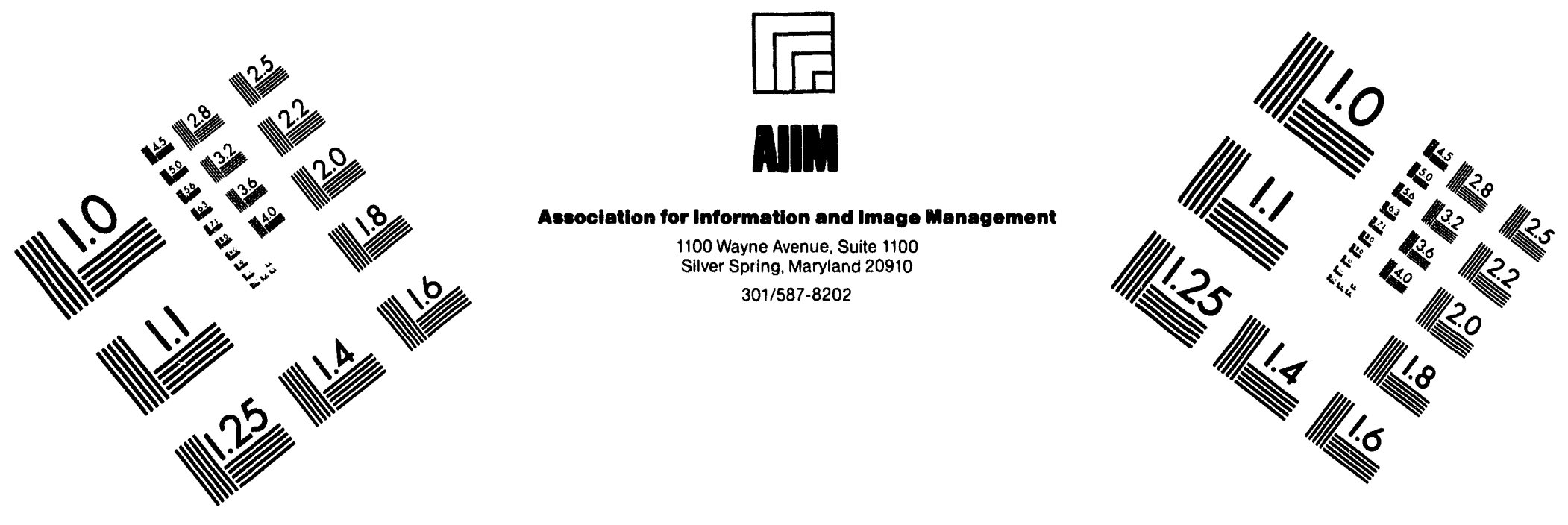

\title{
Centimeter
}

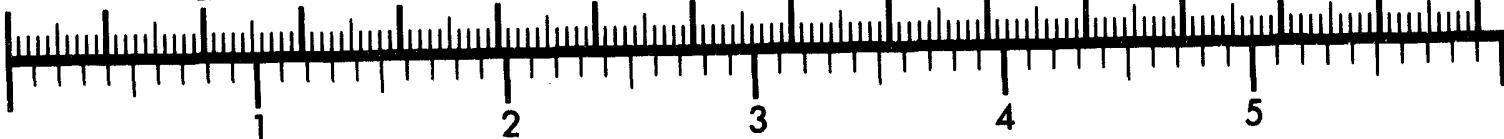

Inches
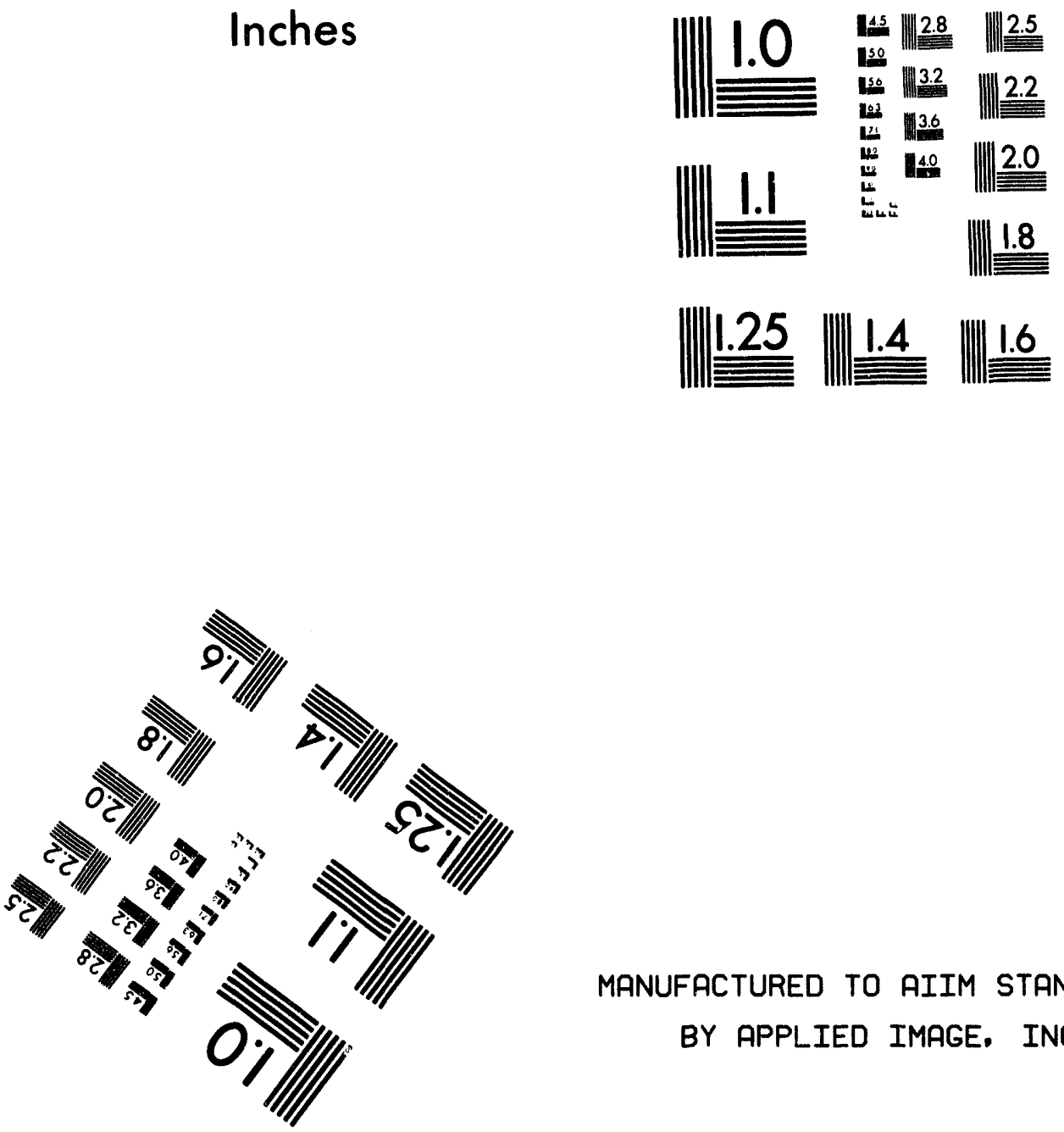

MANUFACTURED TO AIIM STANDARDS

BY APPLIED IMAGE, INC.

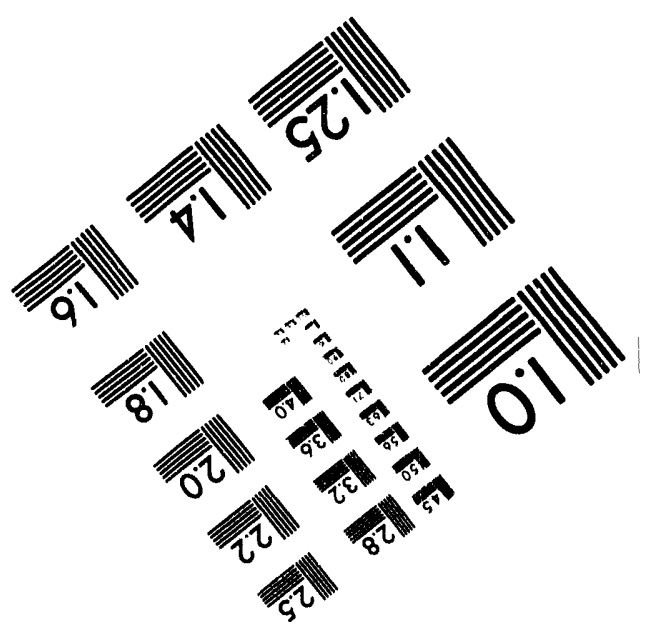



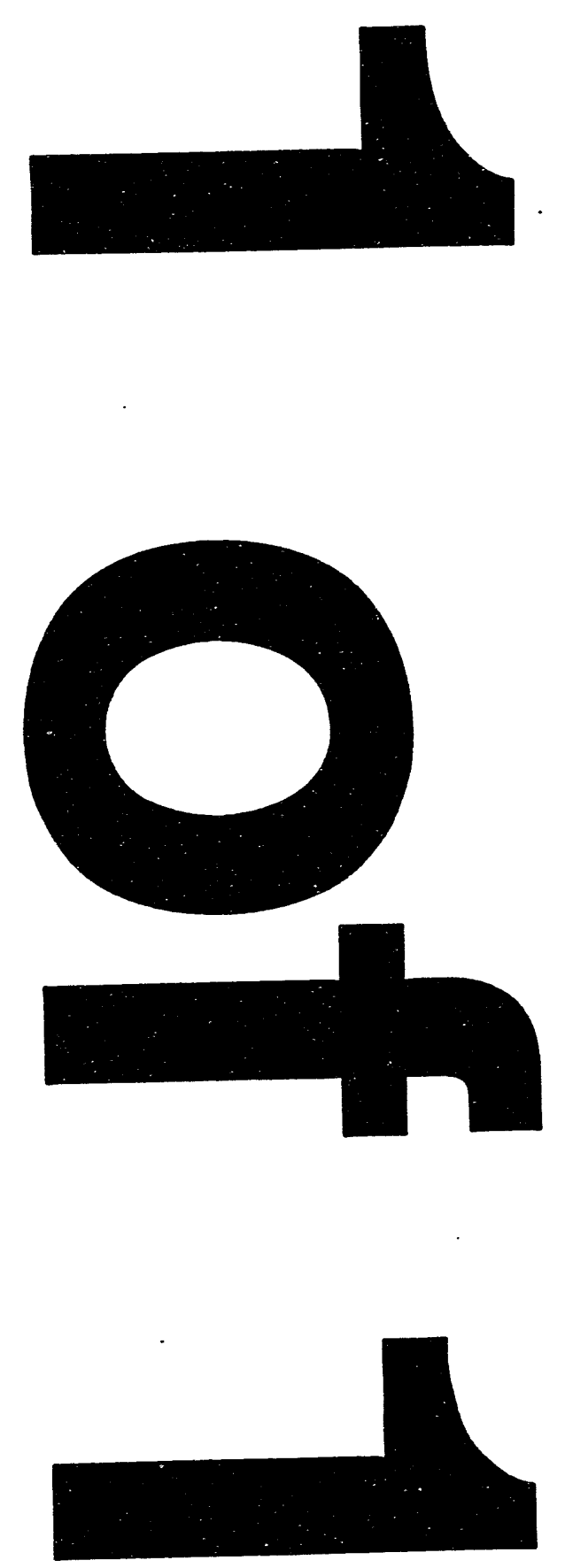


\section{Pollution Prevention Opportunity Assessment Benchmarking: Recommendations for Hanford}

Prepared for the U.S. Department of Energy Office of Environmental Restoration and Waste Management 


\title{
Pollution Prevention Opportunity Assessment Benchmarking: Recommendations for Hanford
}

\author{
J. A. Engel \\ Date Published \\ May 1994
}

For submission to the

Pollution Prevention Group,

Westinghouse Hanford Company

-Prepared for the U.S. Department of Energy

Office of Environmental Restoration and

Waste Management

(2) Westinghouse P.O. Box 1970

Hantord Operations and Engincering Contractor for the

U.S. Department of Energy under Contract DE-AC06-87RL10830

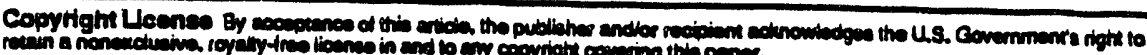

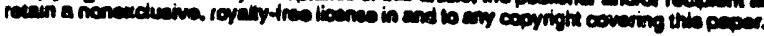


LEGAL DISCLAIMEA

This report was prepared as an account of work sponsored by an agency of the United States Government. Neither the

United States Government nor any agency thereof, nor any of

their employees, nor any of their contractors, subcontractors

or their employees, makes any warranty, expreses or implied,

or assumes any legal liability or responsibility for the

accuracy, completeness, or any third party's use or the results

of such use of any information, apparatus, product, or process

disclosed, or represents that its use would not infringe

privately owned rights. Reference herein to any specific

commercial product, process, or service by trade name,

irademark, manufacturer, or othenwise, does not necessarily

constitute or imply its endorsement, recommendation, or

favoring by the United States Government or any agency

thereof or its contractors or subcontractors. The viows and

opinions of authors expressed herein do not necessarily state

of reflect those of the United States Government or any

agency thereot.

This report has been reproduced from the best available copy.

Printed in the Utritad States of Ameries

DISCLM-2.CHP (1.91) 
POLLUTION PREVENTION OPPORTUNITY ASSESSMENT BENCHMARKING:

RECOMMENDATIONS FOR HANFORD

by .

Jill A. Engel

(509) 376-8737

Westinghouse Hanford Company,

P.O. Box 1970, MSIN H4-21

Richland, Washington 99352

for submission to

The Pollution Prevention Group

Westinghouse Hanford Company 
April 15, 1994

\title{
POLLUTION PREVENTION OPPORTUNITY ASSESSMENT BENCHMARKTNG: RECOMMENDATIONS FOR HANFORD
}

\begin{abstract}
Pollution Prevention Opportunity Assessments (P2OAs) are an important first step in any pollution prevention program. While P2OAs have been and are being conducted at Hanford, there exists no standard guidance, training, tracking, or systematic approach to identifying and addressing the most important waste streams. The purpose of this paper then is to serve as a guide to the Pollution Prevention group at Westinghouse Hanford in developing and implementing P2OAs at Hanford. By searching the literature and benchmarking other sites and agencies, the best elements from those programs can be incorporated and pitfalls more easily avoided. This search began with the 1988 document that introduces P2OAs (then called Process Waste Assessments, PWAs) by the Environmental Protection Agency. This important document presented the basic framework of P2OA features which appeared in almost all later programs. Major Department of Energy programs were also examined, with particular attention to the Defense Programs P2OA method of a graded approach, as presented at the Kansas City Plant. The graded approach is a system of conducting P2OAs of varying levels of detail depending on the size and importance of the waste stream. Finally, private industry programs were examined briefly. While all the benchmarked programs had excellent features, it was determined that the size and mission of Hanford precluded lifting any one program for use. Thus, a series of recommendations were made, based on the literature review, in order to begin an extensive program of P2OAs at Hanford. These recommendations are in the areas of: facility Pollution Prevention teams, P2OA scope and methodology, guidance documents, training for facilities (and management), technical and informational support, tracking and measuring success, and incentives.
\end{abstract}


TABLE OF CONTENTS

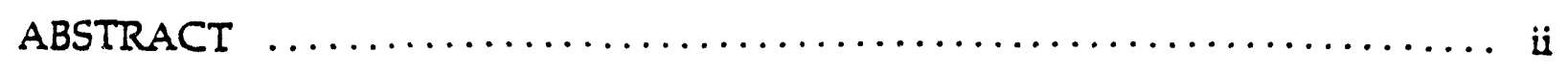

TABLE OF CONTENTS $\ldots \ldots \ldots \ldots \ldots \ldots \ldots \ldots \ldots \ldots \ldots \ldots \ldots \ldots \ldots \ldots \ldots \ldots$

1. INTRODUCTION, or WHY P2OAs? $\ldots \ldots \ldots \ldots \ldots \ldots \ldots \ldots \ldots \ldots \ldots$

2. HANFORD STIUATION \& CRTIERIA $\ldots \ldots \ldots \ldots \ldots \ldots \ldots \ldots \ldots \ldots \ldots$

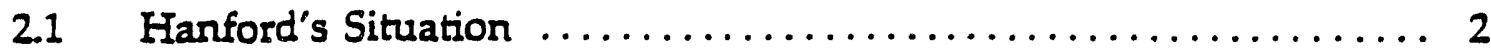

2.2 Regulatory Drivers \& Other Requirements ............... 2

2.3 P2OAs at Hanford Facilities, Past and Present .............. 4

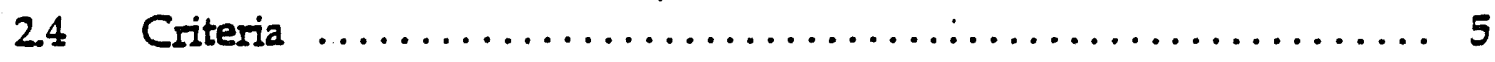

3. CASE STUDIES \& REVIEW $\ldots \ldots \ldots \ldots \ldots \ldots \ldots \ldots \ldots \ldots \ldots \ldots \ldots$

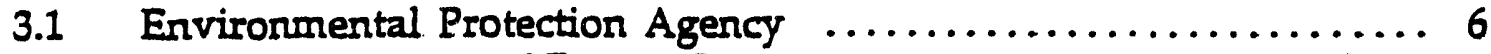

3.2 Other Department of Energy Sites $\ldots \ldots \ldots \ldots \ldots \ldots \ldots \ldots \ldots \ldots \ldots 6$

3.1.1 Production Facilities $\ldots \ldots \ldots \ldots \ldots \ldots \ldots \ldots \ldots \ldots \ldots \ldots \ldots \ldots \ldots \ldots \ldots \ldots \ldots$

3.2 .2 National Laboratories $\ldots \ldots \ldots \ldots \ldots \ldots \ldots \ldots \ldots \ldots . \ldots \ldots$

3.2 .3 Environmental Restoration Sites $\ldots \ldots \ldots \ldots \ldots \ldots \ldots \ldots 9$

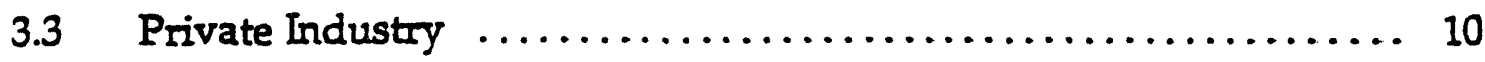

4. P2OA PROGRAM ELEMENT RECOMMENDATIONS $\ldots \ldots \ldots \ldots \ldots \ldots$.

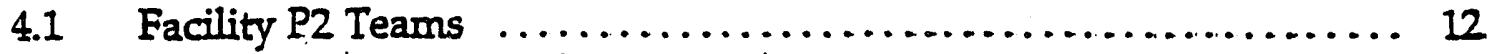

$4.2 \quad$ P2OA Scope \& Methodology ...................... 13

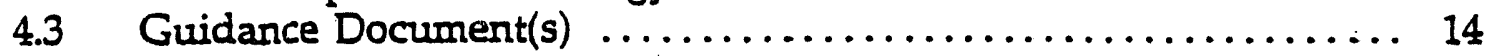

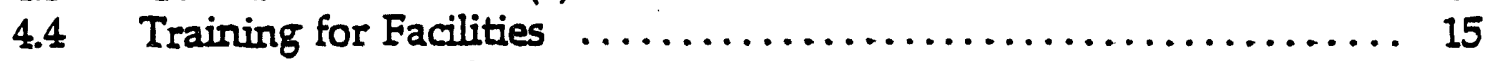

4.5 Technical and Informational Support $\ldots \ldots \ldots \ldots \ldots \ldots \ldots \ldots \ldots$

4.6 Tracking and Measuring Success $\ldots \ldots \ldots \ldots \ldots \ldots \ldots \ldots \ldots \ldots$

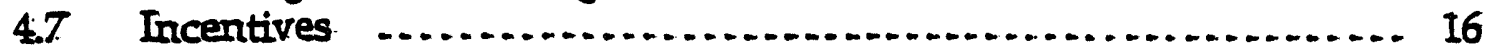

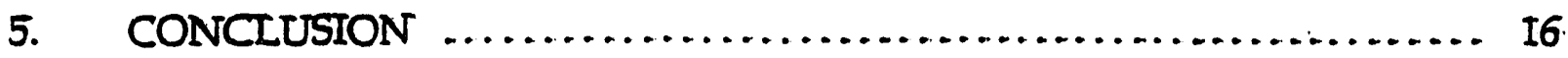

6. REFERENCES $\ldots \ldots \ldots \ldots \ldots \ldots \ldots \ldots \ldots \ldots \ldots \ldots \ldots \ldots \ldots \ldots \ldots \ldots \ldots \ldots$

APPENDDX A: REGULATORY DRIVERS $\ldots \ldots \ldots \ldots \ldots \ldots \ldots \ldots \ldots \ldots \ldots$

APPENDDX B: SAMPLE P2OAs $\ldots \ldots \ldots \ldots \ldots \ldots \ldots \ldots \ldots \ldots \ldots \ldots \ldots \ldots \ldots$ 
April 15, 1994

\section{POLLUTION PREVENTION OPPORTUNITY ASSESSMENT BENCHMARKING: RECOMMENDATIONS FOR HANFORD}

\section{INTRODUCTION, or WHY P2OAs?}

Most people agree that Pollution Prevention Opportunity Assessments (P2OAs) are a critical first step in any pollution prevention program. A P2OA is an activity conducted by a select team which identifies and prioritizes waste streams, examines the processes which cause the generation of the waste, and discovers ways to reduce this waste. Most P2OA programs begin with management commitment as well as the identification and prioritization of waste streams on which to focus. Conducting a P2OA consists of basic steps: selection of a team, gathering of material inputs and waste outputs, understanding the waste generating activity, brainstorming pollution prevention initiatives, and ranking those initiatives. A good $\mathrm{P} 2$ program should also have a method to move from the $\mathrm{P} 2 \mathrm{OA}$ process into implementation of the top initiatives. P2OAs are considered the standard method to identify and rank pollution prevention initiatives. It is used and recommended by the Environmental Protection Agency (EPA), the Department of Energy (DOE), private industry, and other state and federal regulatory agencies.

However, not all P2OAs are alike. Many factors affect how a P2OA should be conducted, including size of the facility or site, number of waste streams, types of waste created, consistency of operations, and resources available. The Hanford site contains 1,450 square kilometers (560 square miles) of land, over 32 facilities, almost 200 hundred on- and off-site waste generators, and thousands of waste sources. Additionally, Hanford's current mission of environmental restoration causes many operations to be discontinuous and project oriented, unlike a production facility. Clearly, Hanford's P2OA process must be able to handle and prioritize the number and uniqueness of waste streams in a manageable fashion.

In order to determine an appropriate P2OA process, the Pollution Prevention group at Westinghouse Hanford Company benchmarked P2OA programs at other Department of Energy sites, guidelines from the EnvironmentaI Protection Agency, and activities of private industry, as well as a few facilities at Hanford already performing P2OAs. Additionally, regulatory requirements were examined and discussions were held with Hanford personnel. Finally, training was taken at the DOE funded P2OA lead site at the Kansas City Plant. This paper presents details on the situation a+ Hanford, comparisons of different established programs, and recommendations for an efficient P2OA process for Hanford.

In order to clarify any confusion with past terms, this note: "Pollution Prevention Opportunity Assessments (P2OAs)" is a new term for what was formerly known as "Process Waste Assessments (PWAs)." . The term P2OA provides a new name for the same function, focusing now on the end result-the discovery of solutions-rather than on a process. Additionally, P2OAs include waste from all activities, not just "processes," and from all media inciuding sanitary, hazardous, radioactive, mixed, air, water, and energy. This being a proactive, positive way of looking at this activity, P2OA will be used throughout this document. Additionally, 
for older documents which use the term PWA, it will be assumed that P2OA could be used in its place now and that the terms are interchangeable.

\section{HANFORD SITUATION \& CRITERIA}

Since the P2OA process is dependant on the facility or site, an evaluation of the Hanford site situation (size, mission, processes, etc.) was conducted. Any P2OAs already being conducted were noted, since what is at work now should not be neglected. Additionally, regulatory drivers and suggested guidance from regulatory agencies were identified. From these, a list of criteria for the P2OA program were identified.

\section{Fianford's Situation}

Initially, perhaps most daunting aspect of Hanford is its sheer size. It includes 1,450 square kilometers of land, about 17,000 employees, hundreds of buildings, and some 30 facilities depending how buildings are grouped. However, communications are currently managed through an excellent computer communication system (cc:mail) and several comprehensive databases. Electronic mail allows for easy file transfer throughout the site. SWITS (Solid Waste Information Tracking System) contains waste generation values for all containerized radioactive, mixed, and hazardous waste, monitored by container and by facility, among others. HMID2 (Hazardous Material Inventory Database) tracks the hazardous inventory at each facility and will soon track hazardous material purchases. So, the computer tools and networks exist to access a wide variety of data and transmit it electronically with ease.

Additionally, several of the large generators on site have established Pollution Prevention (P2) committees, providing a personnel infrastructure to work with and to expand. There is also a central Pollution Prevention Program at Westinghouse Hanford Company.

The second most daunting aspect of Hanford then is the number of and variability of waste streams and processes. Many of the facilities have expressed that they do not know where or how to begin P2OAs when faced with thousands of waste streams. They view each "process," be it one time or repetitive, as the generator of a separate waste stream. Faced with this task, they either fail to begin or focus on simpler measures, such as paper or aluminum recycling. Thus, a method of prioritization and simplification is critical to any program.

Additionally, and perhaps most challenging is the overall mission of Hanford-to clean up and restore the site. No longer is each facility in production mode, but now they each have a different role from each other. These roles are: analytical laboratory services; decontamination and decommissioning/ environmental restoration; clean-up and maintenance; and waste handling and treatment. Some facilities serve more than one of these functions at one time, or will over the next 30 years, the expected life of the cleanup at Hanford. A P2OA program needs to be able to handle this range of missions and activities. 


\section{Regulatory Drivers \& Other Requirements}

Most waste regulation, such as RCRA, make requirements for Pollution

Prevention (P2) as the preferred method of waste handling. More important for this paper, several state and federal regulations drive the conducting of P2OAs and recommend their content, as a method of implementing P2.

DOE Order 5400.1 mandates that all DOE operations comply with "applicable Federal, State, and local environmental protection laws and regulations, Executive orders, and internal Department policies" [U. S. DOE 1, 1990]. 5400.1 also requires a P2 Program Plan in place at each site. A P2OA program could be interpreted as meeting that requirement.

In fact, the Implementation Guidance for DOE Order 5400.1 specifies that "[t]he basic elements of an effective. waste minimization program" includes. "periodic waste minimization assessments/audits" [U. S. DOE 2, 1990]. The order goes on to define these assessments as "a continuing effort," not a "one time endeavor" [U.S. DOE 2, 1990]. It then states that a site should conduct high priority options first, then lower priorities, although no definition is made of how to prioritize. Finally, it suggests assessments look at characterization of waste streams, mapping of the process of waste generation, examining procurement, and finding opportunities. A copy of this section of the guidance can be found in Appendix A.

For Hanford; a significant state requirement is contained in Chapter 173-307 of the Washington Administrative Code (WAC 173-307). This code only regulates hazardous substance users and hazardous waste generators. The requirements for this law are facility plans, priorities/goals, and reporting. The priorities for P2 initiatives are the standard hierarchy of source reduction, reuse/recycling, and treatment. WAC 173-307-030 (2), the section which relates to P2OAs, states the plan shall include:

"...an identification of hazardous substances use and hazardous waste generated by the facility, a description of facility processes, an identification of reduction, recycling, and treatment opportunities, an evaluation of those opportunities, a selection of proposed options, performance goals, and an implementation schedule." [Ecology, 1993]

Even more detait on this can be found in the Pollution Prevention Planning Guidance Manual for Chapter 173-307 [Ecology 1993], which includes 19 worksheets and 5 appendix forms for each facility. Six to twelve of these worksheets are recommended for each hazardous waste stream. These forms cover the items listed in the quote above, with the evaluation of opportunities based primarily on costs.

Besides strict state and federal regulations, DOE has issued two Guidance documents for P2OAs. Before most of the programs were started at the DOE-sites, DOE-HQ issued the Waste Minimization Guidance for Process Waste Assessments [U. S. DOE 3, 1990]. This Guidance should be considered to have some regulatory "teeth" to it. The cover letter that issued this document stated this was to assist in waste minimization efforts and in the compliance with DOE Order 5400.1, 5400.3, and 5820.2a. This letter specifically stated that, "Process Waste Assessments should become one of the standard elements of our current Waste Reduction Program and should be integrated into the program accordingly" [U.S. DOE 3, 1990]. 
The program lays out in general text format the basic steps of a P2OA program. This document is a good, concise, if general, methodology to conducting P2OAs. Of interest is the strong emphasis on management commitment, specifying a written policy statement. Also, they state, "personnel who are assigned to conduct a process waste assessment must be relieved of conflicting priorities..." [U.S. DOE 3, 1990]. Another unique feature is a central task force, which is comprised of senior representatives from the organizational (or facility) units. This group establishes goals, examines technical options, monitors progress, and facilitates technology transfer and P2 awareness. The three appendices in this document list P2OA Team Resources, Source of Material Balance Information, and General Consideration for Prioritizing the Assessment of Waste Streams. Information from these Appendices is including Appendix A. Overall, there is little about prioritizing waste streams, but it has excellent guidelines on conducting a P2OA and ranking P2 opportunities.

Another, not specifically regulatory driver, includes the 1993 Waste Minimization/Pollution Prevention Crosscut Plan. This document strongly emphasizes cost effectiveness and rapid return on investonent from the opportunities found with P2OAs [U.S. DOE 1, 1993]. The Crosscut Plan focuses on all wastes types (not just hazardous), as well as conservation of water and energy, as aspects of pollution prevention. This being the most recent of overall DOE visions, a multimedia program should be developed, as the trend in the future.

Additionally, funding has been provided to Kansas City by DOE-HQ specifically for training other sites to conduct P2OAs. A discussion of their program is included in Section 3.1.1. With this in mind, some care should be taken not to overlap work they have conducted.

\subsection{P2OAs at Hanford Facilities, Past and Present}

When WAC-173-307 was initially enacted, Hanford was exempt as a federal facility. However, in the summer of 1992, DOE made the decision to comply voluntarily. Thus, P2OAs were conducted on over 100 hazardous waste streams at Hanford over the next four months and these were included in the appendix of the Hanford Site Pollution Plan (RL-PPP-92-1). The result of the P2OAs was up to 13 worksheets each stream which included: list of hazardous waste streams, current and past practices, process description, material balance, reduction opportunity identification team, reduction opportunities, reduction opportunity detailed, technical evaluation, economic analysis, prioritize opportunities, selected opportunities and performance goals, and five year implementation plan.

P2 Program staff worked with the facilities to complete these forms on each of their hazardous waste streams. However, limited labor resources, a short time frame, and the detail required precluded extensive personal attention for the facilities. Thus, 20 facilities submitted their forms, while 15 did not. Some forms were not completed fully, the facilities opting to the check the "further analysis needed" box.

However, positive activities seemed to have bloomed from this process. It served to form facility P2 groups where none had been before and strengthen those in existence. Some of the P2OAs resulted in initiatives that were completed. Although no follow-up was conducted to get a specific percentage of initiatives implemented, quantitative P2 activities are reported annually by the facilities. 
While many facilities on-site have $\mathrm{P} 2$ committees of varying levels of activity, three pollution prevention committees were examined for their P2OA processes: the Plutonium Finishing Plant, PFP (conducting clean up activities); the Fast Flux Test Facility, FFIF (not in production, future not determined); and 222-S Labs (analytical laboratories). A Tank Farms P2 committee, as well as some other groups, are beginning to form or are only sporadically meeting. Groups such as Fleet Operations have excellent P2 programs, but no formal committee. At other facilities, P2 reporting is the responsibility of one or two persons who are aware of and report on P2 activity.

PFP has one of the more active facility P2 committees on-site. They meet monthly and discuss their P2OAs, as well as disseminate other information. The committee consists of representatives from each of the divisions of the facility. The manager/team leader's main job is P2 (as well as Safety and ALARA). They classify their streams into large categories, for example "PRF glovebox maintenance," "office waste batteries," and "new/modified coristruction Painting." They have several P2OAs occurring at different stages at the same time. Their forms are similar in content and number as the one's used to gather the Pollution Plan data, but are filled out electronically from meeting notes. A copy of one of their P2OAs is included in Appendix B. In ranking P2 initiatives, they use a weighted sum method with the following criteria (in order of importance), with the ranking in parentheses: eliminates or reduces occupational exposure (13), eliminates or reduces environmental risk (10), retum on investment (4), conserves or reuses resources (4), greatest opportunity for volume reduction (4), reduces waste disposal costs (3), and improves work are housekeeping (1). Overall, they have a successful program which depends on a dynamic leader, interested and active committee members, and a system of forms and tracking that is easily managed. Any site-wide program should be careful not to conflict with an existing successful program.

Recently, FFTF has also completed P2OAs for their maintenance and operations units, and 222-5 labs completed P2OAs on their maintenance operations. Both of these organizations were reborn some time after the site-wide P2OAs and are just starting to have concrete successes. One has had difficulty funding the time of members of the P2 committees. Addilionally, funding for implementation of initiatives is often taken from the same limited budget, larger projects have not found funding. Both groups, while working well together and having excellent leaders, have fallen into the trap of addressing the easy waste streams (aluminum cans, paper, batteries), while unable to make a priority list of where to focus their efforts. On the other hand, they have not been given definitive Guidance from the P2 Group.

Finally, none of the P2 committees thus far have identified energy savings in their assessments. Recent documents from EPA and DOE are beginning to include energy conservation as a method of P2. There exists an energy group at Hanford run through the Pacific Northwest Laboratories. They have not conducted any facility energy audits/P2OAs thus far. 


\section{Criteria}

From the above description of Hanford, discussions with the facilities, observation of how they do business now, and regulatory requirements, the following are the criteria for a P2OA program at Harford:

- Easy to use, understand, and perform quickly

- Flexible to adapt to many streams and facilities

- Applicable to Hanford's ER/D\&D mission

- Uses other DOE work

- Meets reguiatory requirements

- Addresses all waste types (hazardous, radioactive, mixed, as well as solid, liquid, air, water and energy)

\section{CASE STUTIES \& REVIEW}

In order to fulfill the "uses other DOE work" criteria as well as seeking out ideas from other programs, a benchmarking process was done on EPA guidance documents, at several DOE sites, and private industry. Summaries of those programs follow below.

\subsection{Environmental Protection Agency}

As the agency dedicated to the environment, the Environmental Protection Agency (EPA) kicked off the concept of P2OAs with their document The Waste Minimization Opportunity Assessment Manual. This document describes a recommended procedure for identifying waste minimization opportunities. This procedure, as presented by EPA can be seen graphically in Appendix B and became the basis for traditional P2OAs. The steps shown in Appendix B appear repeatedly in the description of plans to follow, especially management commitment, employee involvement/incentives, setting goals, worksheets, material balances, waste stream prioritizing, operator interviews, source reduction concepts, technical evaluation, economic evaluation, and a final report. The document also introduces the use of multiple wortesheets in order to structure P2OAs. EPA. encouraged people using the manual to modify the procedures and forms to fit their own circumstances. Although parts of the document are dated (such as the forward introducing "waste minimization" as a new upcoming term) and the excessive number of forms, this document is by far the most complete and general to date: Even later general EPA documents are not as simple and easy-to-follow-in terms of P2OAs. The Facility Pollution Preoention Guide [EPA 1992] is excellent for a facility just starting a new program from beginning to end. However, it is very process oriented and geared more toward private industry).

EPA has also done significant work with small business through its Waste Minimization Assessment Centers, now Industrial Assessment Centers. This program, managed by universities, funds college students to conduct P2OAs on small manufacturing firms, free of charge. Opportunities recommended are called Waste Minimization Opportunities (WMOs). For one program in Colorado, the average payback period of the sum of initiatives was 1 year, saving the average small firm $\$ 36,000 /$ year in hazardous chemicals alone. Their current focus now is multi- 
media assessments, seeking to reduce hazardous and sanitary waste, as well as conserve water and energy. This Industrial Assessment program is funded by both the DOE and EPA. EPA publishes Research Briefs and other short summaries of waste reduction techniques by process or industry type. These resources of methods to reduce waste would be very helpful in the technical feasibility stage of P2OAs.

\subsection{Other Department of Energy Sites}

DOE sites all have different missions, which affect how they do business and how they conduct P2OAs. This section looks at production facilities, national laboratories and environmental. restoration sites

\subsubsection{Production Facilities}

The first DOE publication on P2OAs that this study was able to find was for Defense Programs. The first edition of the Model Process Waste Assessment Plan [Defense Programs, 1991] based its program on the EPA Waste Minimization Opportunity Assessment Manual, discussed in the EPA section of this document. This first manual is set up as a "cookbook" P2OA plan for a Defense Program(DP) site, including blanks for filling site name, approvals and other site specific information. This document views P2OA teams as offshoots of the waste minimization committee, which chooses the leads for each P2OA. The remainder of the team is drawn from line, staff, or subcontractor organizations. Since it was based on the EPA document, this program is also based heavily on worksheets as a method of guiding the P2OA process. The last Appendix includes 17 worksheets on 43 pages. The forms are modified but very similar to the one's in the EPA document. A more recent edition of this document has been released [Defense Programs, 1993] which parallels the Kansas City program.

The Kansas City Plant is the current P2OA training center for DOE and has received special funding for this endeavor. Thus, it is important that DOE work at other sites does not duplicate the significant volume of work completed at Kansas City (KC). However, it is also important to note that the Kansas City Plant is still a production facility, producing various parts and equipment for Defense Programs. Their program has been designed to handle the over I500: waste streams the have identified and on which they have or plan to conduct a P2OAs. However, they have left the door open to D\&D and ER work (and plan to explore this option in the future) by their definition of a "Process" as "Any existing or planned operation or activity which generates waste or pollution to the air, water, and/or land" [Kansas City, 1993]:

$\mathrm{KC}$ 's approach is also based on worksheets, 10 of them for the full approach. Their forms are simpler and easier to follow than the EPA's forms, but include basically the same information. Where $\mathrm{KC}$ differs from previous programs is the concept of the graded approach. Presented in more detail in the Defense Programs document Model Pollution Prevention Opportunity Assessment Guidance, this approach introduces the concept of three levels of detail for P2OAs, based on the prioritization of the activity. (This approach also expands the concept of prioritizing waste streams more fully than other programs to date). The graded approach is designed to be a "cost-effective and flexible methodology which allows individual sites to prioritize their local concerns and align their efforts with resources allocated, 
while also providing some consistency throughout the DOE to perform P2OAs" [Defense Programs, 1993]. They view less complex P2OAs as appropriate for small or less-toxic waste streams.

The first step in the graded approach is the develop a priority material/waste stream list, a list of material inputs and waste stream outputs which are most important. They strongly recommend including the following on this list. waste with no approved disposal method, waste which is more than $5 \%$ of facility total waste stream, Clean Air Act Class I materials (Ozone clepleting chemicals), EPA 33/50, and known human carcinogens. Their "suggested" items seem to include everything else, i.e. waste that is regulated, permitted, a health/safety risk, and muricipal solid waste.

The next step is to perform a Level I assessment on the process. Level I defines the process through description and a flow diagram, documents what waste minimization activities have already been done, and determines if more analysis is needed. This is about 3 worksheets, which includes a simple process flow diagram with "fill in the blanks" for inputs and outputs. The final question asks if this process involves materials or wastes from the priority list. Following a logic diagram, if the answer is no, then this assessment stops. If the answer is yes, then a weighted sums criteria sheet is completed to determine if a Level II or Level III assessment should be completed. A stream that scores under a certain value in weighted areas of criteria, gets the level II assessment; over that score, a more detailed Level III assessment. Level II goes directly into brainstorming options, estimating their feasibility, costs and savings, and summarizing (total of two more worksheets). A Level II P2OA is included in Appendix B. A Level III expands the P2OA team, expands the flow diagram worksheets, completes a detailed mass balance, evaluates material cost, and includes more complex forms for option generation, an evaluation of initiatives by more weighted sums, and a detailed final report (total of 10 more worksheets).

A final component of the Kansas City program is the integration of their forms onto computer software. While they began their P2OAs without any computerized tracking or reporting, they recogrized the advantages of a tracking program and centralized collection point. They use a database management . program called FileMaker Pro, which runs on the both the Apple-Macintosh and Windows based systems with no file conversion required. The software is relatively easy to run, but some training is required to attain proficiency. The data is entered by each P2OA team as assessments are conducted.

Overall, the Kansas City Plant and the Defense Program P2OA programs are excellent, especially the concept of a graded approach. However, the level of detail they require for the typical P2OA is only appropriate for a site with regular processes. Kansas City listed all their processes and is conducting P2OAs on them over the next. few years. A site undergoing clean-up, environmental restoration, or significant lab research needs to have a faster, truly on-going program. Still, the Kansas City program can be a basis for this kind of flexibility.

\subsubsection{National Laboratories}

The national laboratories have also been at work on their P2OAs. One of the most published is the Idaho National Engineering Laboratory (INEL). Their waste 
generation tends to be from thousands of small processes, as well as some D\&D work being conducted. They started their P2OA program in late 1990 in response to the DOE PWA Guidance. While including many of the basic steps, their worksheets tend to be simpler and less structured that Kansas City's or EPA's. This correlates with their laboratory, and not production, mission and was done by design. They describe the forms in the following manner.

Because the EPA worksheets were too complex and cumbersome to be of use to the trainees, the idea of not providing or requiring worksheets was discussed. INEL-specific worksheets were developed, because such worksheets would serve as an outline of PWA requirements. These worksheets met the requirements, but were flexible enough to aid in the completion of any type of PWA [Lientz, 1992].

INEL encouraged people conducting the P2OAs to change the forms to fit their process, if need be, not the other way around.

During the initial training sessions, INEL $\operatorname{ran}$ into resistance from the P2 coordinators of three areas: laboratory operations, research and development (R\&D) and environmental restoration (ER), including decontamination and decommissioning (D\&D). They felt that PWAs were inapplicable to them because their programs were variable and unpredictable. INEL provided them with extra "assurance" that these activities may not be as well defined but there exists many waste reduction opportunities in them. In the case of lab waste, the lab coordinator looked at the thousands of experiments he had and concluded that PWAs could only be conducted by grouping. The lab processes were grouped into 5 categories: collection and disposal of excess chemicals, inventory and procurement of chemicals, photographic laboratories, acid-analytical laboratories, and experimental waste. The wastes within each group were then identified and prioritized based on quantity and toxicity. Then the activities that generated the priority wastes were identified and examined for waste reduction opportunities. Once one waste stream was completed, then the next on the priority waste stream was done. D\&D/ER was handled by conducting the P2OA before the activity. A P2OA was conducted in a checklist form and had to be included in the DED plan. Overall at INEL, P2OAs were conducted with an emphasis on "flexibility as well as a common sense approach" [Lientz 1992]

INEL also included a resource package in the training, which included management support documentation, P2OA requirements, example P2OAs, technical information of P2 solutions and helpful resources. INEL has also developed a computer database/reporting program, but is currently examining other options.

Like some of the areas at INEL, Los Alamos National Laboratories (LANL) as a whole was initially resistant to conducting P2OAs. They felt that they were a large site (43 square miles) and, as a lab, had such a diverse collection of sources with similar processes existing in many locations that P2OAs would not be cost-effective. So, they developed a program with three criteria: usable by the generator, flexible in the level of detail (graded approach), and provides access to outside information on possible solutions. Since much of the generation and material flow information was already computerized at LANL, they decided to institute a full-blown electronic 
P2OA system, based on computer modelling (for material flow), a graphic information system (for facility locations), and links into databases of generation and solutions information. They view it as a "environmental information system" linked to computers throughout the site. The system is in limited use now, without the graphic interface. A prototype of the complete system is complete and a production version is scheduled to be completed by the end of FY 1994.

\subsubsection{Environmental Restoration Sites}

The current mission at an increasing number of DOE sites is one of environmental restoration (ER), which usually includes decontamination and decommissioning (D\&D). D\&D consists primarily of shutting down and removing structures, while ER includes the cleaning of soils, groundwater, and the return of the land to a more natural state. Some sites such as Hanford have this as their primary mission, while others such as INEL are conducting ER as well as other missions. The critical concem with ER sites is that the majority of waste generated is by one-time processes, often on large scales (such as cleaning up and tearing down a building). The traditional P2OA, which relies on analyzing a continuing process, is not possible.

Some discussion of D\&ED at INEL is in Section 3.2.2., where they recommend P2OAs be conducted before the activity, in the form of a checklist. However, in conversations with INEL personnel, they do not currently conduct P2OAs on D\&D /ER wastes, with the exception of repetitive processes such as sampling analysis and Health Physics surveys.

In order to do a brief survey to determine what other sites might be doing in this area, the text descriptions of P2 activity and the site missions of the 1991-92 Annual Report [U.S. DOE 1993] was examined. Two sites that seemed to be conducting P2OAs, had a ER mission and a contact name through the Kansas City P2OA resources document were contacted-the Weldon Spring site and the Oak Ridge K-25 site.

The Weldon Spring Site Remedial Action Project is a 230 acre site 30 miles west of Saint Louis, Missouri. The site had been used for an ordnance works for the Army and for processing uranium and thorium by the Atomic Energy Commission. Now the site is on the EPA National Priorities list and has a full ER mission. In a phone conversation with a representative of the site as well as from their P2 Awareness Plan [Weldon Spring 1991], they conduct aimost all their assessments prior to the beginning of the activity. This "Waste Minimization Analysis" is conducted according to a formal procedure. This procedure covers two major activities: a review of all requisitioned hazardous materials and a review of all activities which plan to generate new waste. Substitute chemicals are recommended, as well as what P2 activities should be implemented. Documentation of this process is required for each activity or requisition, with a 3 page form for the waste generation activities [see Appendix B].

Weldon Spring has identified their key elements as reduce newly generated waste; focus on waste from heavy equipment; and control chemicals coming in. They also do training for sub-contractors, have conducted an involved P2OA on personal protective equipment, and have segregated their D\&D waste, hoping to recycle in the future. Overall however, they expressed that they were struggling 
with how to deal with non-process waste, setting goals, showing progress, and getting releases for recyclable demolition wastes. They are seeking other solutions.

Oak Ridge K-25 Site was formerly used for enriching uranium for the Oak Ridge site. The diffusion facilities were shut down in 1985 and the K-25 site is currently preparing for D\&D operations starting in 1995. Shortage of funding has been the primary problem for P2OA work for $K-25$, though that is starting to change through the efforts of K-25 employees. Although they have conducted P2OAs in the past on several consistent waste streams (oil, fluorescent light bulbs, sludge, photographic waste), this year they are focussing on the pre-assessment stage. They are developing priority waste streams, process diagrams, and setting goals. Next year, money will be available for conducting P2OAs. They have looked at ER/D\&D, via excessing and recycling large pieces of equipment. However, they have no formal pre-evaluation phase.

Overall, this study did not find any site that seemed to have a complete grasp on how to handle D\&D and ER waste. Many sites are aware of the problem, and it has been a recurring theme at conferences. Kansas City's DOE training program is considering addressing this kinds of waste, due to the call for it by many sites. Hanford alone estimates that D\&ED waste will account for $9 \%\left(39,100 \mathrm{~m}^{3}\right)$ and the ER will account for $30 \%\left(129,400 \mathrm{~m}^{3}\right)$ of the total waste generated over the 30 year cleanup of the site [Westinghouse 1993]. Certainly, with the entire DOE-complex downsizing and decommissioning, D\&D/ER wastes will need to be addressed.

\subsection{Private Industry}

Many private industries have been proactive in term of Pollution Prevention Assessments. DuPont Chambers Works in Washington worked actively with EPA in a two year project assessing 15 waste streams. The implementation of initiatives from 7 of the assessments reduced those waste streams by $73 \%$. Implementation of initiatives from all 15 assessments (now in progress) has the potential to save the company almost $\$ 15$ million per year [DuPont 1993]. This is only one example of the manufacturing savings being found by companies such as $3 \mathrm{M}$, Proctor \& Gamble, Intel, and the many small businesses helped by EPA [Price, 1993]. However, the method of conducting P2OAs used by these companies is basically the method recommended by EPA and apply primarily to production firms.

However, some of these firm's programs are unique and could be applied to Hanford. Important success criteria from private industry include: prioritization of waste streams, definite rate of retum required for project implementation, progress tracked and communicated, responsibility and accountability tied into P2 success, recognition for employees, integrated into pre-manufacturing decisions, inclusion of P2 a separate budget, use of recycling as well as source reduction, and the use of new technology [Price 1993]. These criteria differ in significant ways from the DOE/EPA focus on regulations, worksheets, committees, and reduction programs.

In an effort to tap the people resource, incentives and recognition must also be included. Hanford is a leader in cost saving incentive programs for employees, and $\mathrm{P} 2$ initiatives can be submitted to them. However, another interesting program, with a more technical bent, is being used by the Louisiana Division of Dow U.S.A. Dow began an energy conservation program in 1981. It began and grew into an annual Contest for employees, where employees submitted ideas to reduce waste, 
save energy and increase yield. The contest is aimed at engineers in the plant, and the current rules are that projects must save at least $\$ 100,000$ /year and have a return on investment greater than $50 \%$ ( 2 years). The program has been an unqualified success, surprisingly saving more money each year, with increasing participation. Dow credits the success of this program with these qualities:

- Sustained management support

- Organized central committee (focal point) including engineers and an economic evaluators.

- Started small

- Developed grass roots support

- Encourages people with problems to look for solutions

- Kept paperwork simple ".

- Reviewed project before implementation

- Hold contest once a year, fitting in with budgeting process

- Contest committee does not control capital, managers still do

- Winners receive only recognition-not cash!

- Worked through existing line organization-no new level of hierarchy

- Credit goes to Plants

- Educites and trains people

- Audits of implemented projects (follow-up on success/failure)

- No goals (for specific reduction)

- No gimmicks (professionally run)

- No monthly newsletter (but they do a project summary each year)

- Give people ideas (not projects)

Their primary concept. The way you reduce waste is by installing projects that reduce waste. And although these qualities and this concept is for a contest, many of these could be directly applied to a P2OA program.

\section{P2OA PROGRAM ELEMENT RECOMMENDATIONS}

Based on the criteria specified for Hanford in Section 2.4 and the review of other sites and sources presented in Section 3.0, the following recommendations of critical elements to be included in a P2OA program are being made. They are separated into 7 general program categories. All of these will require more development for their implementation.

\subsection{Facility P2 Teams}

Facility P2 committees should be the central working unit for P2OAs. This committee forms the central P2 team from which originates P2OA teams.

First, the definitions of the facilities at Hanford should be finalized as much as possible. Waste generator groups, groups of like facilities, might also be a method to allow a single team to cover a larger scope. However, facility or waste generator group definitions should not break up existing committees, nor should they be artificial and uncomfortable to the existing facility culture. 
Implementation of the P2OA program should begin with the existing P2 committees, making sure committees have appropriate management support. Simultaneously, management support should be fouind for facilities with no existing committees, in order to form them. A possible so. urces of this support is through the environmental compliance officers (ECOs).

Committees should have representatives from each part of the facility and consist of all range of job functions, including and especially bargaining unit employees. Committee members should be volunteers, not appointees.

Committee members should be given enough time by their managers to adequately serve on the team and perform the necessary functions. At least 4 hours/week for P2OAs (including the researching of viable altematives) and another 2 hours monthly for the central P2 meeting.

The P2 committee leader should be able to dedicate a significant portion of her/his time to P2 activities. At least fifty percent of their time is recommended. They should be knowledgeable about P2, and an advocate.

The P2OA teams will form and un-form from the main P2 committee. Each P2OA should have its own lead, who takes notes, completes any forms and does follow-up. They also keep the project on schedule. Preferably, the lead should be someone from the area that has the majority of the waste generation activity.

The central committee will decide which P2OAs should be conducted. After a waste stream is identified, the P2OA team, lead by the assigned leader, will conduct the interviews and gather all background information. After presentation of the facts to the main P2 committee, the entire committee will conduct the brainstorming. The cost estimates and viability will be conducted by the subgroup. The entire process should take 1 month for background information gathering, 1 meeting for brainstorming, and 2 months for idea evaluation. More detail on each of these steps is presented in Section 4.2. Several P2OAs should be conducted simultaneously, a new one started each month, ideally.

Finally, it is very important for the P2 committee to work actively with management to get ideas implemented after they have been shown to have significant benefits. While not part of the P2OA process, this step is critical to the success of the program. Igain, the team P2OA leader with help from the P2. committee leader will work to implement the selected opportunities as quickly as possible.

\subsection{P2OA Scope \& Methodology}

P2OAs should be an on-going activity, based on a total quality/ continuous improvement approach. The purpose of P2OAs is to be the organized mechanism to implement activities that reduce waste.

The assessments include the following steps (based on EPA guidance and KC training): choosing a priority waste stream, mapping a flow diagram, interviewing / gathering data, brainstorming opportunities, evaluating of ideas, and recommending implementation.

The first step for P2OAs should be prioritization of waste streams through a priority waste stream list. Waste streams and materials should be listed from SWITS, HMID2, projections, and other facility records, and should include any projected waste from ER/D\&D activities. A new list should be generated each year, 
even if all the priority streams were not addressed the previous year. All waste types should be included, not just hazardous (hazardous is less than $5 \%$ by volume of the total waste generation). Also, energy and water should be included as "material" streams, i.e. the list should be multimedia, including waste (haz, rad, mixed, sanitary), air, water, and energy.

The list of waste streams should then be prioritized. Facilities should be allowed to develop their own criteria, but Guidance for important items should be given, based on the KC approach (graded approach priority list). This list should certainly include cost and volume as criteria. The entire list should be ranked in an order, not just a list of items that have equal priority [see Defense Programs, 1993, pages 3-5]. The waste streams list should be inclusive, but manageable, grouped such that there are 20-40 materials and streams per facility. Possible grouping categories exist in the Projections report [Westinghouse 1993].

Next, the "graded" approach (like KC) should be applied. However, the approach should be imbedded into the program in the following way. Instead of focusing first on the process and determining if it should have a level I, II, or III approach, focus on the stream (like INEL). Example: The P2 committee chooses its first waste stream from the priority list. A P2 committee member of the facility is assigned P2OA team lead on this stream. First, all the activities that contribute to this stream are listed, including quantities. These activities now automatically qualify for a P2OA Level II or II since they generated/use a priority waste or material. A number of activities, no greater than 3, are chosen that as a sum contribute over $50 \%$ of the waste stream. A Level II P2OA will be conducted on these activities simultaneously. This method saves time in that there is no long activity list to sort through to determine if they qualify, and this method focuses on the waste or material, rather than the generating activity itself. Also, at Hanford, no Level III P2OAs should have to be conducted, since they are excessively detailed for the Hanford situation.

A level II P2OA should include the following, besides filling out $K C$ worksheets (or equivalent) 1S, 2S, and 3S [see Appendix B]: visiting the process area, interviewing operators and people performing the work, reviewing any appropriate documents (transportation records, etc.), plotting the generating activity, and. summarizing all materials and waste streams. It is important to ask the operators what they think should be done (on the spot brainstorming by people who could not be on an official team).

Once the background assessment is compete, a short, graphical presentation of facts to the main P2 committee should be done by the P2OA leader. Brainstorming should then be conducted by the P2 committee, using any "on-the spot" ideas or ideas generated by the P2OA team during the assessment as seeds. Generated ideas do not have to focus on the priority waste stream, but can be on any waste reduction ideas for that activity.

Research then should be conducted into the technical and economic viability of the brainstormed ideas by contacting vendors, procurement, and other resources. Ideas can then be listed and ranked, such as in KC worksheet 4S. All accepted ideas should have a payback of less than 2 years $(50 \%)$. Final results should be presented to the P2 team on worksheet 5S, and the entire assessment to management for approval. 
P2OAs on D\&D and ER would be conducted in a similar way, but the P2OA would not be conducted when the activity is happening, but as part of the planning process. If a D\&D/ER project will be one of the main generators of a priority waste stream being examined, then the final planning documents should be obtained. These should list the expected wastes generated. Then, the P2OA team should conduct a P2OA on them in the same way as above, but by examining the plan (like Weldon Spring).

All forms should be Hanford-specific and based on KC worksheets 15-55, but kept simple enough for any P2OA type.

\subsection{Guidance Document(s)}

Two Guidance documents should be prepared to support P2OAs: a detailed one for the facilities; and a summary guide for management.

Hanford Facility Guidance should be issued, based on the EPA Guidance and the Defense Programs Guidance, but with emphasis on prioritization of waste streams, sources of info for Hanford, and how to handle one-time processes and laboratory waste. The Guidance document should include steps for conducting P2OAs for a regular activity (which would include observing the process) and for $D \& D / E R$ (inserted in the planning process).

The main portion of the document should show, in words and graphics, the steps to conduct a general P2OA as described in section 4.1 and 4.2. Additional sections should cover: evidence of management support; an introduction with a "why do it" portion; regulatory drivers; an example of several kinds of P2OAs; a chapter on how to measure and track progress; how to change the general steps for labs (mainly how to group activities); and how to change for D\&D/ER (mainly look at before activity begins).

Appendices should also include specific Hanford contacts and systems for information retrieval, plus a reference document for technical solutions. If these are done in appendix modules, they can easily be updated individually as needed. The reference module would include many of the EPA facility specific guidelines as 'vell as numerous contacts. Finally, there would be guidelines for implementation. of projects, including basic Elanford procurement policy and who to contact Overall, the document shovild be written in plain language and in procedural format.

The Guide for managers would explain the benefits, briefly explain the program, explain what to expect from their P2 committee, and explain appropriate budgeting. This document should be very concise (2-3 pages) and clear.

\subsection{Training for Facilities}

As there are two Guidances, there should also be two training sessions. The longer, workshop-style training would be for the facility P2 committees. A shorter introduction meeting would introduce the program to mariagers.

Each facility training session should be for a single facility committee. This training is not a repeat of the work of $\mathrm{KC}$, but rather a method of providing Hanford-specific information to the facilities. As much waste stream information should be given to the facilities at the training (or before) as possible, including their facility's waste stream lists from SWITS and hazardous inventory from HMMD2. 
Sources of information for other items, such as water, air, energy and sanitary waste (which have no central tracking system) should be provided. Before the facility training, trainers and attenders should be aware of general waste inputs, streams, and activities at their facility. This data can be gathered in a coordinated effort between the Pollution Prevention group and the P2 Committee team lead.

The training should not be over half day long and should be facility specific.

Provided in addition to training materials should be a resource package, which would include the Guidance document (which includes P2OA examples and resources), evidence (such as a formal letter) of their managements support, and printed waste streams and materials specific to their facilities.

There should also be a preliminary meeting for the management of the facility about the undergo training. The P2 committee leader should actively participate in their management's training with the P2 group. This clarifies what would be presented in the Management Guide described in section 4.3.

\subsection{Technical and Informational Support}

Support to the facilities shall be provided from the pollution prevention group. It should include help obtaining written management support. Also, a formal network of facility representatives should be formed, either a central task force or some other mechanism for communication between facility teams. Finally, a techrical support network should also be developed, including a library, a database of existing P'2OAs completed, and a personal knowledge of resources of P2 initiatives and technologies. As much of this as possible should be provided to the facilities in the continual updating of the resource package, the remainder being on central file and $a$ list of the files provided to the facilities. This resource should be used as seeds for brainstorming and research material for viability and cost research into P2 brainstormed ideas.

\subsection{Tracking and Measuring Success}

While the Los Alamos National Laboratory's kind of computer system is very forward-thinking and certainly the way of the future, attempting a project of this scale is too ambitious for rapid implementation at Hanford. The concept of keeping it simple and starting small should be applied. A standard database format, such as Excel, should be examined for initial tracking, making sure any data to be tracked is specifically asked for on the P2OA forms. This database could then be used in any later tracking systems.

Any tracking system should involve continual reporting as P2OAs are accomplished, and as ideas are implemented, not as a year-end data call. The tracking system should also include a method to measure progress by the individual facility, not just the central P2 group. This gives the facilities a way to show their manager what they have accomplished, as well as giving them more autonomy.

Certainly, computerization of the P2OA process should be conducted in the next 2 years. Thus, LANL's system and KC's system should be examined for their possible use at Hanford in the future. 


\subsection{Incentives}

Several methods for incentives can be used. One of these is to develop a catchy name for initiatives, such as EPA's "WMO-Waste Minimization Opportunity," pronounced "Whammo." Also a slogan would be good, if used professionally, such as "An Ounce of Prevention is worth a Pound of Cure" (or An ounce of pollution prevention is worth a pound of clean-up; An ounce of prevention is worth a pound of remediation; etc.)

Even more important would be to initiate a way for employees to submit ideas not necessarily related to formal P2OAs. A model for this would be the DOW contest, which focuses on the technical and the professional, rather than giveaways.

Certainly, any P2 incentives should tap into current WHC incentives programs, such as ECCEL and STI. Information about these programs and how to apply for them should be provided to the facilities.

\section{CONCLUSION}

By examining the literature published and talking with employees of so many programs and organizations, one can see that P2OAs are an excellent technique to identifying ways to reduce waste. In fact, the basic $\mathrm{P} 2 \mathrm{OA}$ requirements as introduced by the EPA, are still valid and were included in the recommendations for this paper. However, a few new elements needs to be included, all of which were mentioned in other programs but not emphasized. These include waste stream prioritization, flexibility, and preplanning on ER/D\&D activities.

It is critical that waste streams be prioritized before any P2OAs are conducted. With a site the size and diversity of Hanford, the focus must be ont he large, expensive, or particularly toxic waste streams.

Second, the P2OA program must be flexible. Each facility team, which will be conducting the P2OAs will need to be able to adapt any program to their own situation.

Finally, since a significant portion of Hanford generated waste over the next 30 years will be directly from ER/D\&D activities, it is absolutely critical to get the pollution prevention mentality into the designers of D\&D/ER plans. The best way, . often mentioned by other programs, but not in significant implementation yet, is through a P2OA process on the plan itself.

This concludes the research and the literature search for P2OAs. Now begins the implementation of a P2OA program at Hanford. 


\section{REFERENCES}

Defense Programs, 1991. Model Process Waste Assessment Plan. United States Department of Energy, Office of Defense Programs, Washington, D. C., January 15.

Defense Programs, 1993. Model Pollution Preoention Opportunity Assessment Guidance. United States Department of Energy, Office of Defense Programs, Washington, D. C., December.

DOE 1, 1990. DOE Order 5400.1, General Enoironmental Protection Program. United States Department of Energy, Washington, D. C.. June.

DOE 2, 1990. Implementation Guidance for DOE Order 5400.1. United States Deparment of Energy, Washington, D. C., March.

DOE 3, 1990. Waste Minimization Guidance for Process Waste Assessments. United States Department of Energy, Washington, D. C., October 17.

DOE 1, 1993. 1993 Waste Minimization/Pollution Preoention Crosscut Plan (predecisional draft). United States Department of Energy, Washington, D. C., December.

DOE 2, 1993. Annual Report on Waste Generation and Waste Minimization Progress 1991-1992 (draft), DOE/S-0105. United States Department of Energy, Washington, D. C., November.

DuPont 1993. DuPont Chambers Works Waste Minimization Project, EPA/600/R93/203. Environmental Protection Agency, Washington, DC, November.

EPA 1988. The EPA Manual for Weste Minimization Opportunity Assessment, EPA/600/2-88-025. United States Environmental Protection Agency, · Cincinnati, Ohio, April.

EPA 1992. The Facility Pollution Preoention Guide, EPA/600/R-92/088. United States Environmental Protection Agency, Cincinnati, Ohio, May.

Ecology, 1993. Pollution Preoention Planning Guidance Manual for Chapter 173-307 WAC. Washington State Department of Ecology, Olympia, Washington, September.

Kansas City Plant, 1993. Process Waste Assessment Training. United States Department of Energy, Kansas City Division, Kansas City, Missouri, November. 
Lientz, Amy and Joel Schurke, 1992. "Implementing Waste Minimization at the Idaho National Engineering Laboratory," Federal Facilities Environmental Journal, Winter.

Price, Randy S., 1993. "Benchmarking Pollution Prevention: A Review of Best-InClass Facility Programs." Pollution Preoention Reoiew, Winter.

Weldon Spring, 1991. Waste Minimization/Pollution Predention Awareness Plan, DOE/OR/21548-124. Weldon Spring Site Remedial Action Project, U.S.

Department of Energy, Weldon Spring, Missouri, May.

Westinghouse, 1993. 1993 Solid Waste Reference Forecast Summary, WHC-EP0567-1. Hanford Project, U.S. Department of Energy, Richland, Washington, August.

Special thanks for the pleasant telephone and personal conversations on their P2OA programs goes to the following people:

Belgin Barkenbus, Oak Ridge K-25

Rachel Damewood, Idaho National Engineering Laboratory

Joe Estey, Plutonium Finishing Plant, Hanford Site

Emma Lou George, Environmental Protection Agency

Dave Hickson, Weldon Springs Site

Mike Kostrzewa, Colorado State University Industrial Assessment Center

Dave Leviten, Pollution Prevention Research Center

Tom Lyttle, Los Alamos National Laboratories

Rob Nielson, 222-S Laboratories, Hanford Site

Susan Pemberton, Kansas City Plant

Mickey Seamans, Fast Flux Test Facility, Hanford Site

Jeff Weinrech, Los Alamos National Laboratories

Staff of Pollution Prevention Group, Hanford Site 
April 15, 1994

\section{APPENDD A: REGULATORY DRIVERS}

This Appendix includes:

- Sections from Implementation Guidance for DOE Order 5400.1 [DOE 2. 19901, pages A2-A3.

- Sections from Waste Minimization Guidance for Process Waste Assessments [DOE 3 1990], pages A4-A6. 
From Implementation Guidance for DOE Order 5400.1 goals (1.0.. 57 to 157 yearly or a spectfle perearit by a spectfied year) for reducting the volume or toxic1ty of each waste stream should be set, after performing an lnitial assessment of techrical and conomic feasibility. This lnitlal assessmant could be performed on hlgh prlorlty wast streams, 1.e.. ruch as waste with hlgh volume or high disposal costs, waste hIghly regulated or oven bansed from disposal. avallablltt of technology, ete. The goals should be correlated with producton rates. Even 18 information on waste generation forecasts is faloly 1mprectse, some waste minlmization goals should be established early in the program with the lenowledge that thase. goals wilI be rev1sed is accordance with future reflnements in waste generation projectlons and wast management analys1s.

D. Perlodic Waste MLnimization nssessmente. Ind1uldual production processes or facillties should be reviewed or audited periodicaliy to 1dentify opportunites to minimise or elfminate waste generater. The results of these assesanent should be reported beck to the waste gerarators. 1.e.n. productedor. operations staff. Larger factllties corrid estabilsh a taam of Independent experts. IhIs process is not a one-time endeavor but a contlnuing effort. Once the high prlarlti waste mintmizaten optlons have been implemented. the lower prlorlth optlons shorid be examised for opporturiteles to further inisimize waste. generation. [NOTE: The PIOCess Waste Assessments described in the draft AppIled Research, Development, Demonstretelon, Testelng and Evaluation Flve-Year PIan are equivalent to these wasto minimization assessments, and may be substituted at the Brogram and Operations Offlces' discretion.l The wast minimization assessments should, at minimum:

I. Examise the available data on the types, amounts, and hazardous constftuents of wastes generated, 1.e.. characterlize the waste streams.

2. Examtne where, why, and how these wastas are generated - withis the production process- Irade materiale that eventualiy wind up as waste from the recelving docke to the polnt at which they become a waste.

3. Determine the true costs of the wastes generated. The Operations offices should develop some means to calculate the costs of the materials found in the waste stream, perhaps based on the purchase price of those materials, and the costs of managing. the wastes that are generated, including regulatory compliance costs.

4. Perform an assessment of procurement pollcles. Data on procurement might include unit slze, standing order size, non-hazardous substitutes, and surplus avaliability. Evaluation of such data could lead to 
greater overs1ght of procurement and better control on waste generation at the source.

5. Ident1fy opportunitles at all polnts in a production process where materials can be prevented from becoming a waste, 1.e.. potantial souree roduction and recpeling technlques applicable to those wastes.

\section{EXAMPLES:}

- Ident1fy opportunities for recycling materials within the production process.

- Explore ways to optimize or change procesa parameters, such as flow rates, temperature or residence times, to minimize waste generation.

- Examine process design or operation improvemants that may resuIt in reduction in chanicals consumed, Increase the Ilfe-time of equipment, or avold the use of hazardous materlals.

- Examine ways to eliminate or segregate unnecessary equipment from ereas easily contaminated (e.g.. hot CeIIs).

-Evaluate technology changes orlented toward equipment modiflcatlons: These might include changes in the production equipment, layout or plpling, and the use of automation.

- Examire contamination control barciers so that spiIIs can be contalned and the materlal returned to use rether thar disposed.

- Evaluate opportunittes for extending the service Iffe of filters or exchange columss through operational. modifications.

- Develop an assay system so that suspect-contaminated waste can be sorted Into contaminated and noncontaminated categorles.

E. Accurate Cost nccounting. Departments and managers should be charged for the waste management costs of the wastes they generate, 1.e. collection, handling, packaging, transportation, treatment, storage, and disposal. Liabllity insurance and regulatory complifance costs, such as personnel, permitting and recordkeeping. should also be charged. The ldea is that if department managers are held accountable for the waste they are generating, they will be motivated to avoid generating the waste 
Ecom Waste Minimization Guidance for Process Waste Assessments

12

APPENDIX A

\section{PROCESS WASTE ASSESSMENT TEAM RESOURCES}

Listed below are typical team member skills and resources needed for the PWA. Because facilities vary in size and functions, the list is not meant to be exclusive. All skillis may not be needed on all teams. Some team members may be part-time; certain skills may be selected to provide expertise on an "as needed" basis.

Chemical Engineering

Environmental

Facilities/Maintenance

Finance/Accounting

Human Resources/Personnel

Information Systems.

Legat

Maintenance

Materiat Contral/Inventory

Monitoring and Comptiance

Process Engineering Production

Project Management/Scheduling

Public Information

Purchasing/Procurement

Quality Assurance

QuaT ity Control

Research and Development

Safety/Heal th

Shipping/Receiving/Transportation

Waste Treatment and Disposal 


\title{
APPENDIX B
}

\section{SOURCES OF MATERIAL BALANCE IMFORMATION}

Listed below are potential sources of information for preparing a material balance inventory. The list is not meant to be exclusive.

\author{
Batch Make-up Records \\ Design Material Balances \\ Emissian Inventories \\ Equipment Cleaning and Validation Procedures \\ Material Inventories \\ Operating Logs \\ Operating Procedures and Manuats \\ Production Records \\ Product Specifications \\ Purchasing Records \\ Samples, Analyses, and Flow Measurements \\ Waste Manifests.
}


APPENDIX $C$

GENERAL CONSIDERATIONS FOR PRIORITIZING

THE ASSESSMENT OF WASTE STREAMS

Compliance with current and future regulations

Costs of waste management (treatwent and disposal)

Potential environmental and safety liability

Quantity of waste

Hazardous properties of the waste (including toxictty, fl ammability, corrosivity, and reactivity)

Other safaty hazards to employees

Potential for (or ease of) minimization

Potential for removing bottlenecks in production or waste treatment

Potential recovery of valuable by-products 


\section{APPENDLX B: SAMPLE P2OAS}

This Appendix includes:

- EPA Waste Minimization Assessment Procedure from The EPA Manual for Waste Minimization Opportunity Assessment [EPA 1988], page $B 2$

- A P2OA from Hanford's Plutonium Finishing Plant, pages B3-89.

- A Level II P2OA from Kansas City's Process Waste Assessment Training, pages B10-B19:

- D\&D/ER P2OA forms from Waste Minimization/Pollution Preoention Awareness Plan [Weldon Spring, 1991], pages B20-B22. 


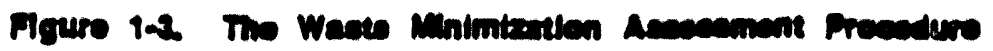

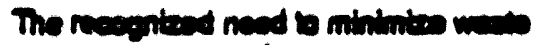

$\downarrow$

planme and onenuratron

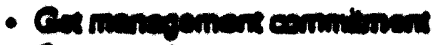

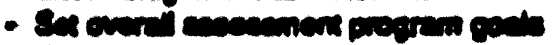

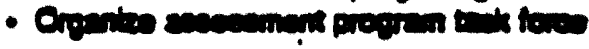

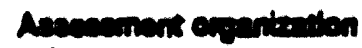

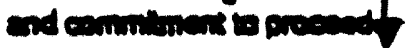

Acangumer muex

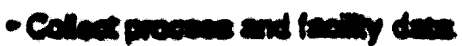

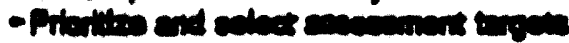

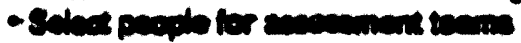

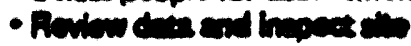

- Comoras coplena

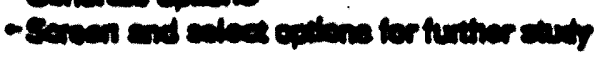

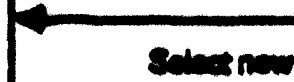

comenom

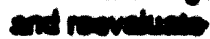

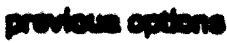

Acomanom report of

colnond exing

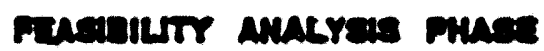

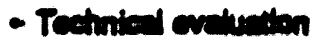

- Econande crilumedor

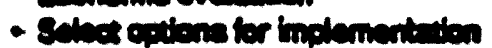

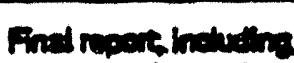

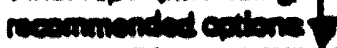

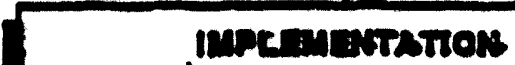

- -

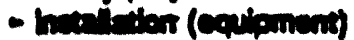

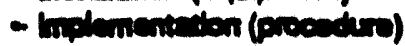

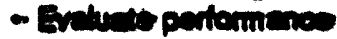

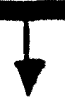

Succeacatully implemented

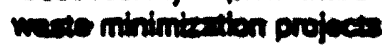


Doxingoet 2

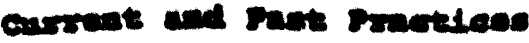

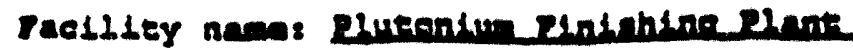

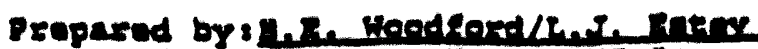

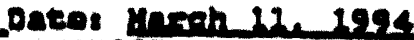

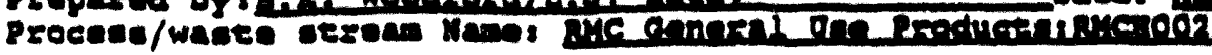

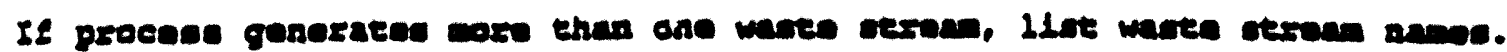

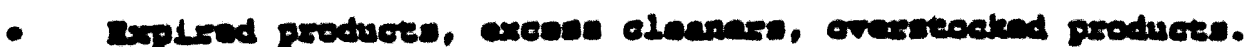

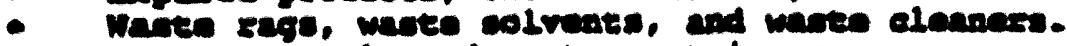

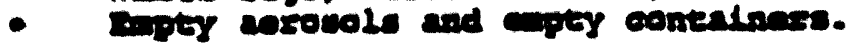

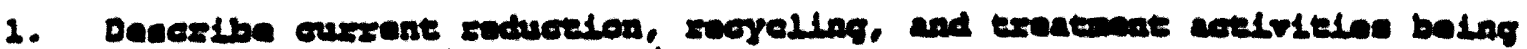

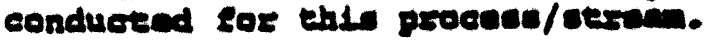

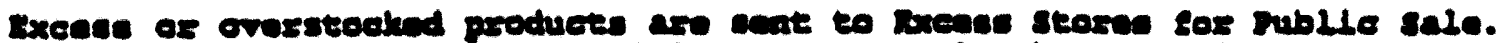

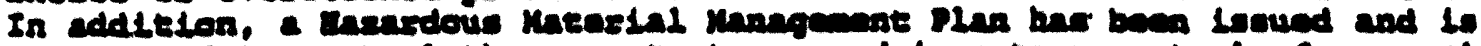

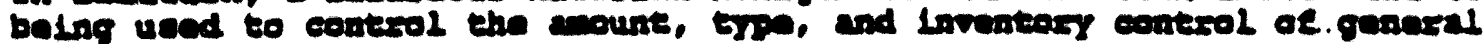
use products at int.

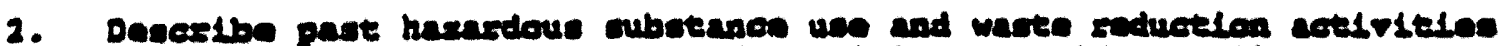

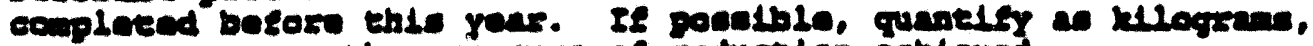

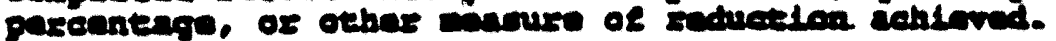

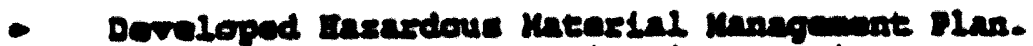

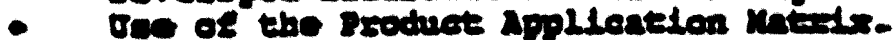

- roplemanted conterolied chentor Invinex.

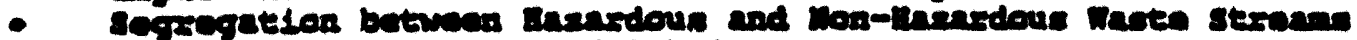
ineluding wote rege and lubsleanten.

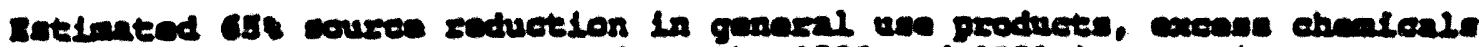
and overuteoked Ltem cempared to the 1990 and 1991 Liventeriten.

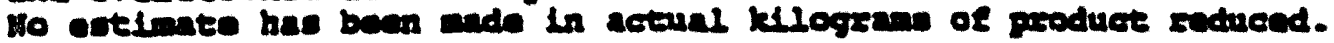

Example B20A Erom Banford's Plutonium Btnishtng Plant 
Norkshoet 2

Process Docerst predoa

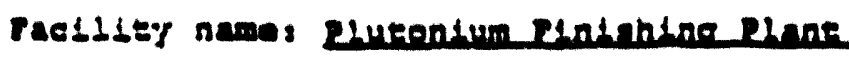

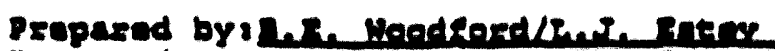

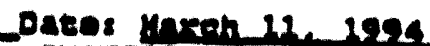

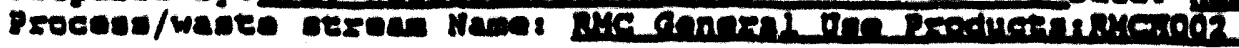

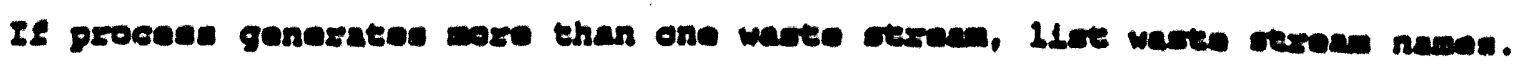

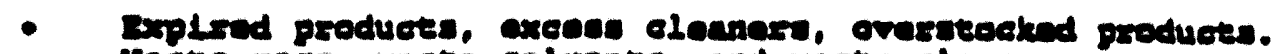

- Mave sage, wate colvonte, and warte eleanose.

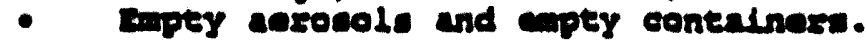

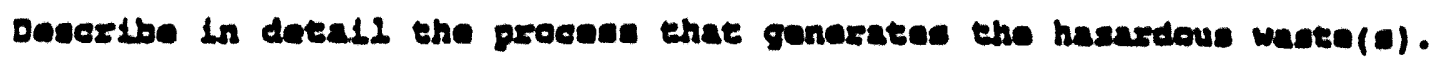

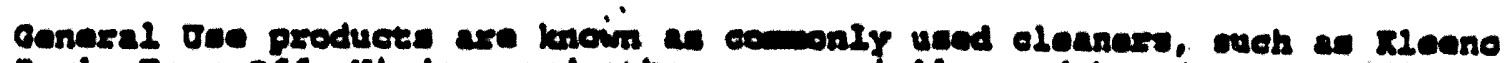

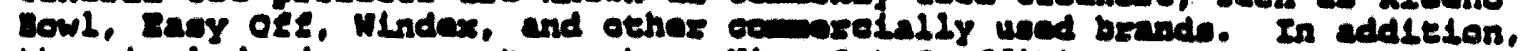

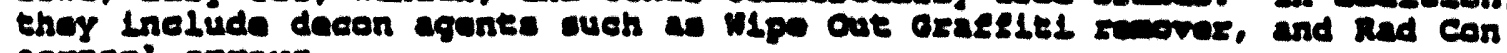
cosecol apreys.

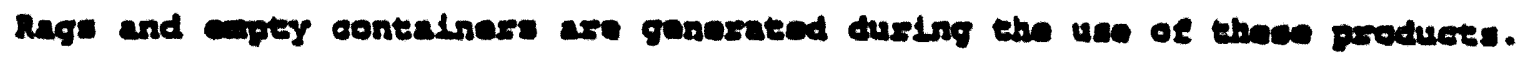


Doskenteot 3

Materind Elaneo

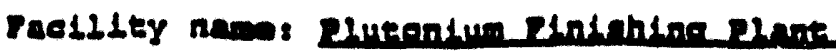

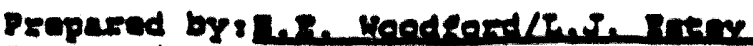

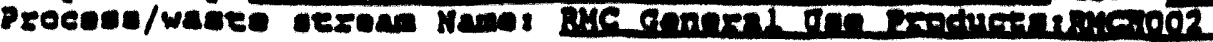

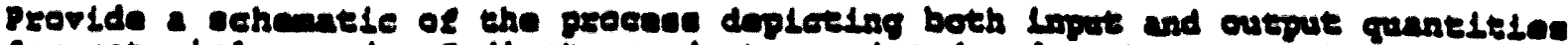

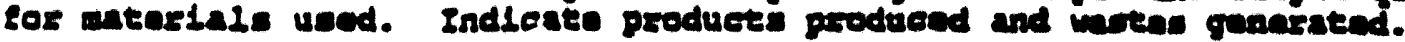

\begin{tabular}{|c|}
\hline \\
\hline \\
\hline \\
\hline 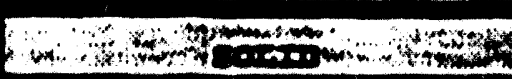 \\
\hline
\end{tabular}

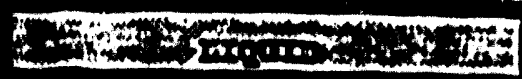

- Cloviner. correnlve

- Clenners, non-tende

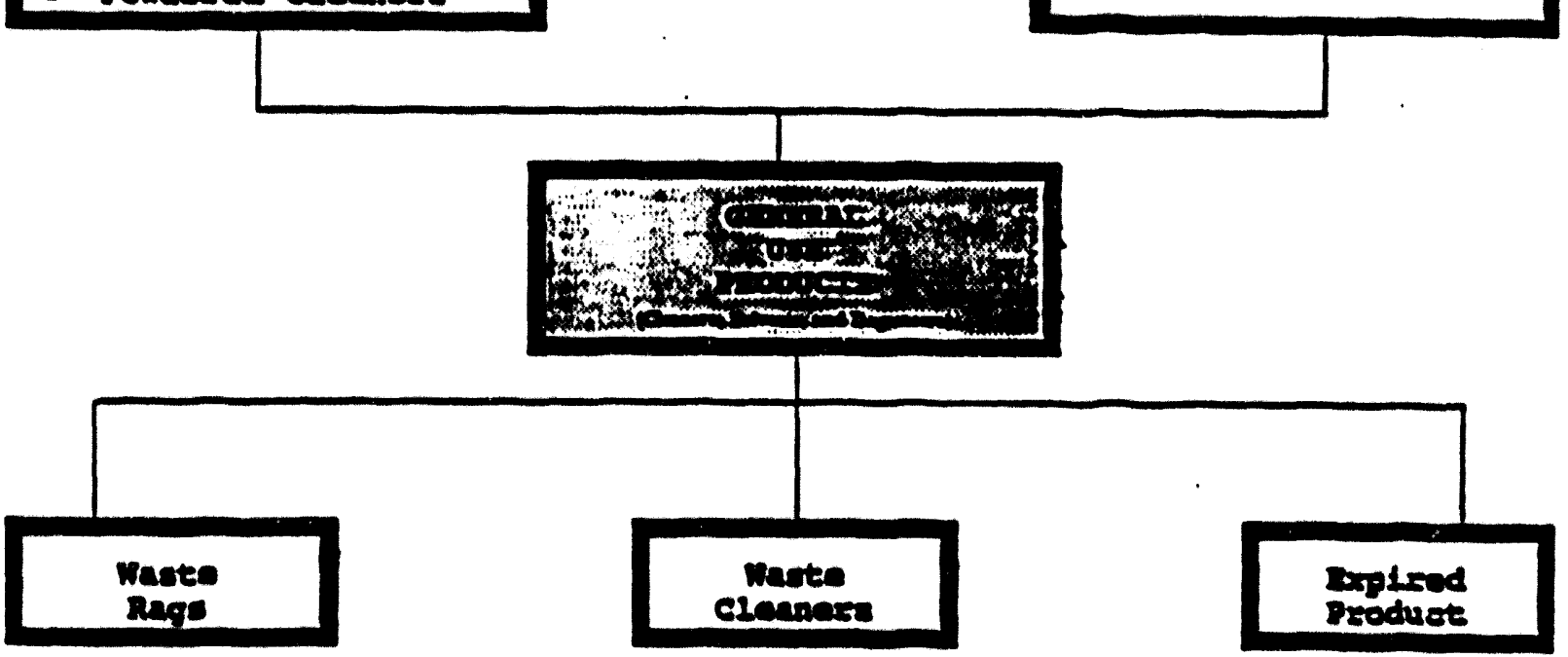


Torkerbeet 4

Roduction Oppostundtios Ideatsleation ran

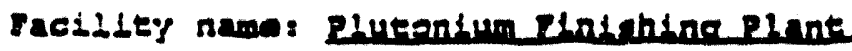

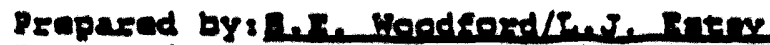

Dates Inreh 11 , 1994

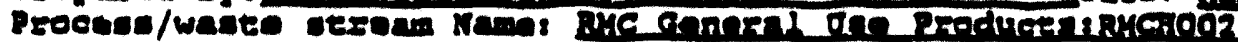

Mrmbersion

Adrent phon

c. S. Bare

270-8 noem 22

2006

$373-1921$

D. A. Brador

234-92

Roew 102

$200 \%$

$373-2398$

D. H. Buske

$234-92$

Roew 107

200n

$373-3411$

J. R. cosmuall

$234-52$

Roow 252

200w

$373-3890$

B. D. Devin

234-92 Room 254

20019

$373-5768$

L. 5. Batey

234-52 · Reen 202

$200 \%$

$373-3387$

B. A. Johnotene

234-92 Roen 323

2001

373-2509

3. A. Jones

234-58 Roen 13

$200 \%$

$373-3347$

P. A. Pownll

$234-5$

Inbozateory

$200 \mathrm{~s}$

$373-2211$

R. I. gulater

$234-58$

Roco 2221

2000

$373-2864$

R. I. Rhoters

$234-58$

Rocm 107

$200 \%$

$373-3411$

I. H. Robortenor

$234-52$

Inbartery

$200 \mathrm{r}$

$373-2211$

B. 2. Moodsozd

270-2 Roci 42

$200 \%$

$373-4448$ 
Norkersoot 5

Reduetion Oppostundtese

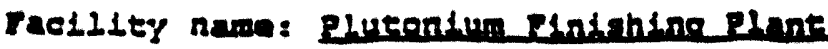

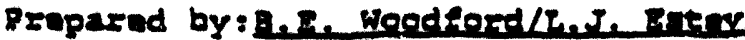

Dates Hefh 1 H, 1994

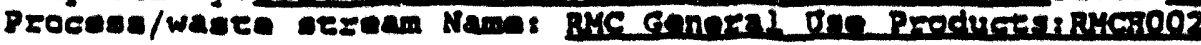

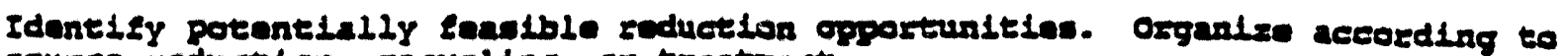
souree zuduction, reffeling, or trustumte.

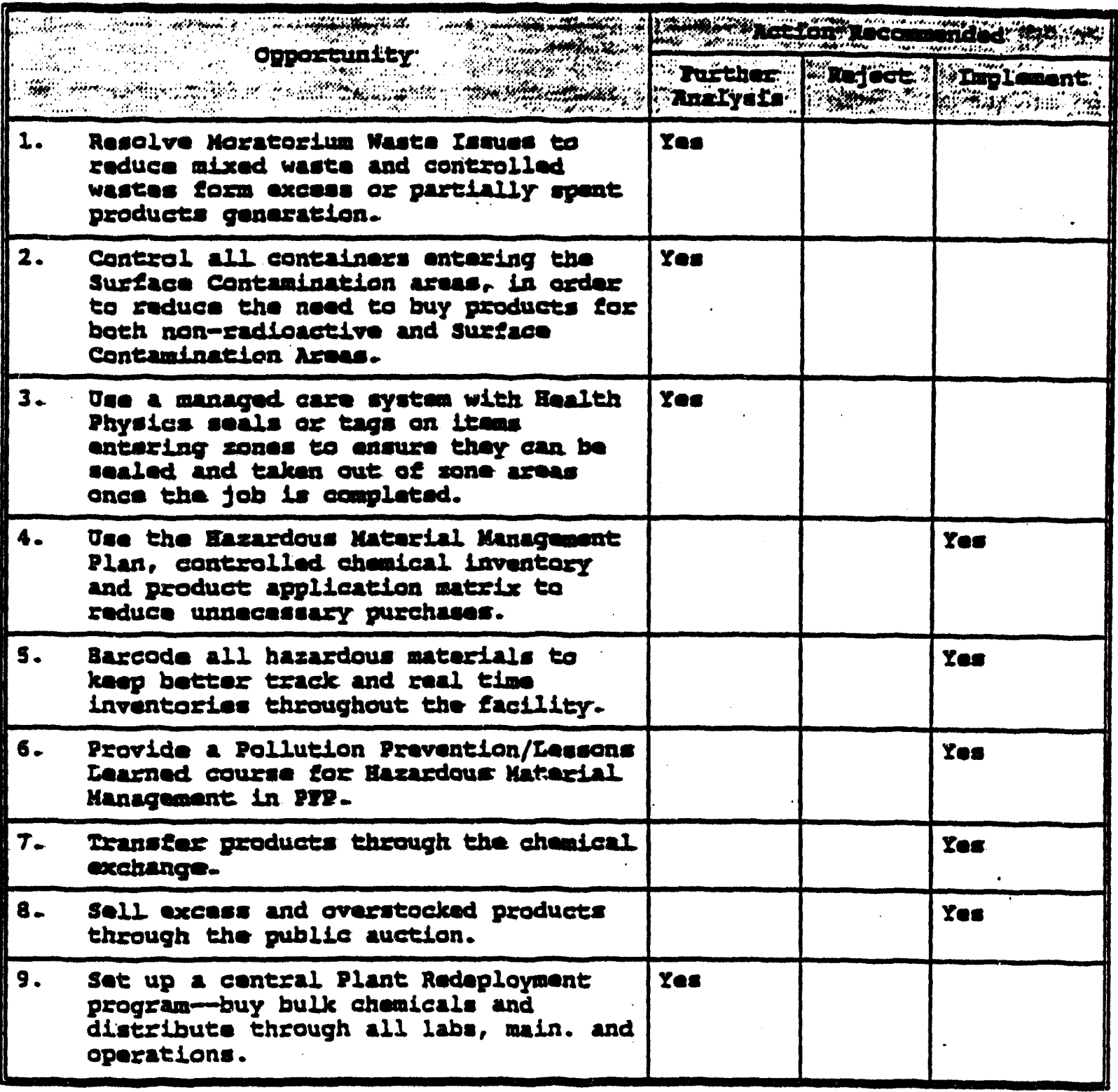




\begin{abstract}
Nozksteret 0
Reduction Opportunity Detall

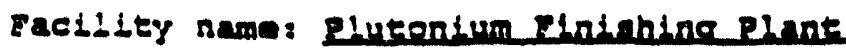

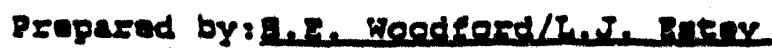

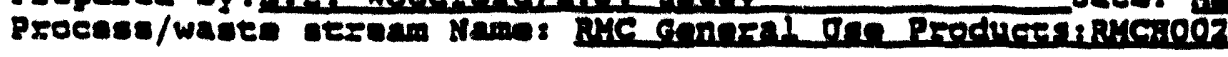

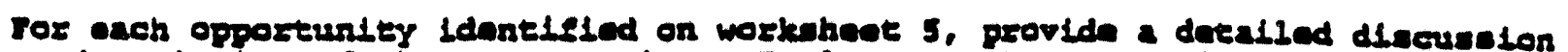
or doneription of that opportunity. Fvaluate ench opportundty using tho criterid providnd ho ivaluaton checkline.

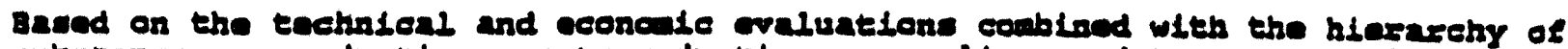

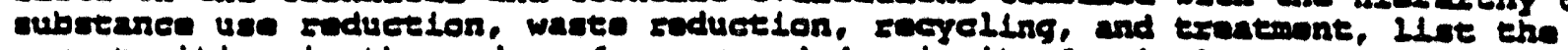
opportunition in the order of zecominded priority for implementation.
\end{abstract}

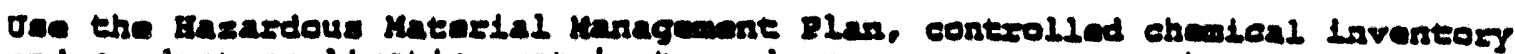

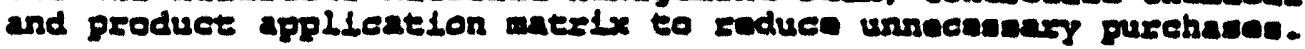

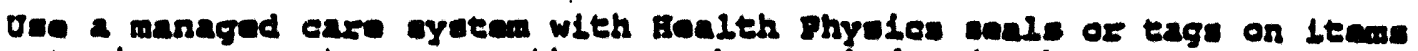
ontering zones to envure thoy can bo coaled and taken out of zone arene once the job to comploted.

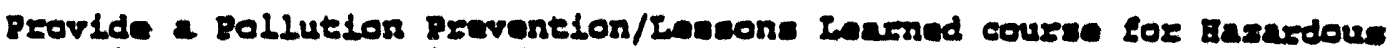
Material Maragnant in PTP,

Control all contalners ontering the surface contanination arean, In arder to reduce the nead to buy producte tor both non-zadioactive and surtsen contamination Reer.

soli axcien and overztocked producten through the publle auction.

sot up a centeral plant Redoploywent program-buy bulk chealcale and disteribute through all labe, mals. and operations.

reanefor producte through the chenleal exchange.

Barcode all hazardoug materiale to kap botter track and raal time inventories throughout the sacility.

Resolve koratorium Nante Incuen to soduce mixed wate and controlled wartes form excese. or partially opent products genoration. 
Fosieshose 7

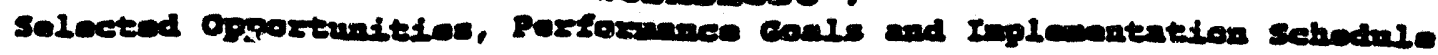
Facility name: Plutentum phinhino plante

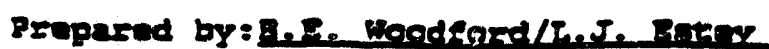

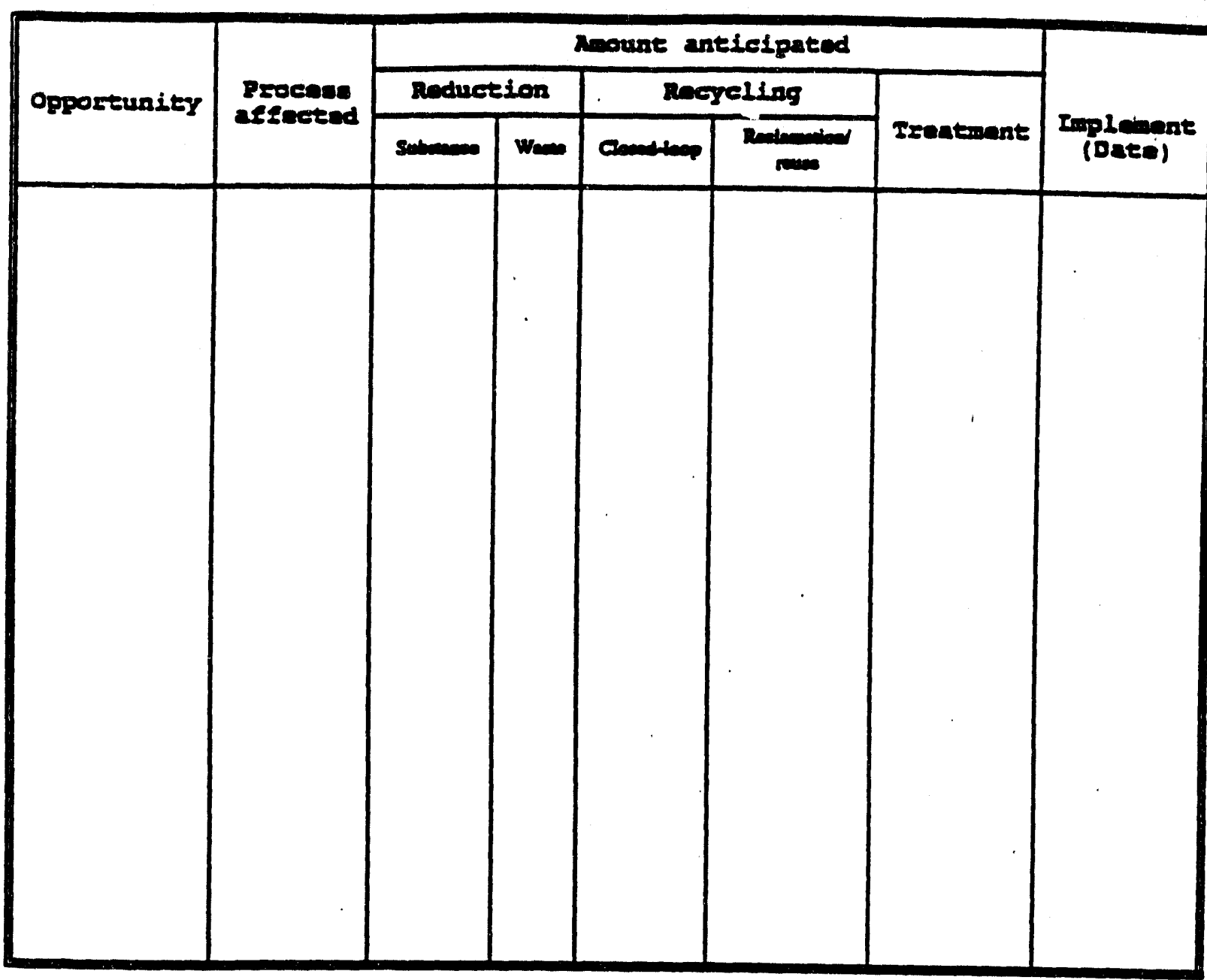

If it is not penctical to oteablinh numerie goals, list objectives designed to lead to goale as noon as practicuble. 
Levil

Page 1 Date: $\frac{\text { 9R103 }}{1}$

\section{Pollution Prevention Opportunity Assessment}

\begin{tabular}{l} 
Team \& Process Description \\
PHe: Laboratory Glasoware Cleaning \\
\hline
\end{tabular}

Team Membars ('Laader)

Job Classification

Phone

- Iim Ellott

Lab Technician

$x-7142$

T. Joe Pemberton

Lab Tectnician

$x-7154$

Susie Taylor

Lab Technician

$x-6433$

Process Description:

The lab technician is required to collect $75 \mathrm{mLday}$ (5 times a week) of sulfuric acid solution and transfer it to a chemical etching tank. After collecting the acid and transferring it to the tank, the technician immediately cloans the graduated cyllinder. The process consists of deaning the graduated cylindar. The acid solution makeup is included in the PWA for the etch tank. The graduated cylinder cleaning is accomplished by triple rinsing with acetone. The cylinder is then allowed to air dry. Rinsing is performed in a laboratory sink that is connected to a sanitary sewer line. The sink is located in a ventilated booth approved for fiammable liquids. The laboratory technician is property trained to clean glassware.

i Potential for Pollution Provention or Recommendations:

There is potential for pollution prevention. Jim Bob Ellott has many ideas and recommends further analysis to generate waste minimization opportunities. 
This worksheet provides the scope and identification of the pollution prevention opportunity assessment (PPOA) team. For the PPOA to be successful, employees involved with the activity being assessed should be members of the team. The assessment team needs a leader, members, and additional resources, as required.

The team leader should have technical knowledge of the area's operations and the personnel involved. The leader shall assemble the team to perform the assessment. Team members may include engineers, waste generators, waste management specialists, scientists, laboratory technicians, and other line personnal. Additional resources may be utilized to provide information not available within the team. The size of the team may be large for complicated operations, but should be kept to a minimum to maintain focus.

1. Date: List the initiation date for this PPOA.

2 Tite: List the PPOA title selected by the team.

3. PPOA ID Codo: List the PPOA ID Code selected by the team. This should be a unique identifier.

4. Team Members, Job Classification, Phone: To facilitate team meetings and for future reference, this information should be completed when the PPOA team is formed.

5. Procases Deseripton: This should detail important attributes of the operation. Equipment, summary of operations performed, controls, input materials, and operator training (qualification or certification) may be included.

6. Potential for Pollution Prevention or Recommendations: For this process, describe the potential for pollution prevention, source reduction, and/or waste minimization. (Is there any pollution prevention potential for the following changes: material substitution, procedures, process parameters, equipment, general practices, recycling, reuse, reclamation, etc?) Are there any recommendations for this process? 


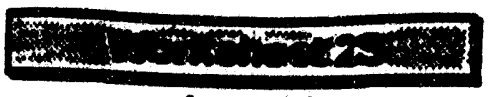

Levell 1 .

Page 1 or 1

\section{Pollution Prevention Opportunity Assessment}

Process Flow Dlagram

Tith or Asscasment ID Coda: CLPTO16-LABCLEAN-OY

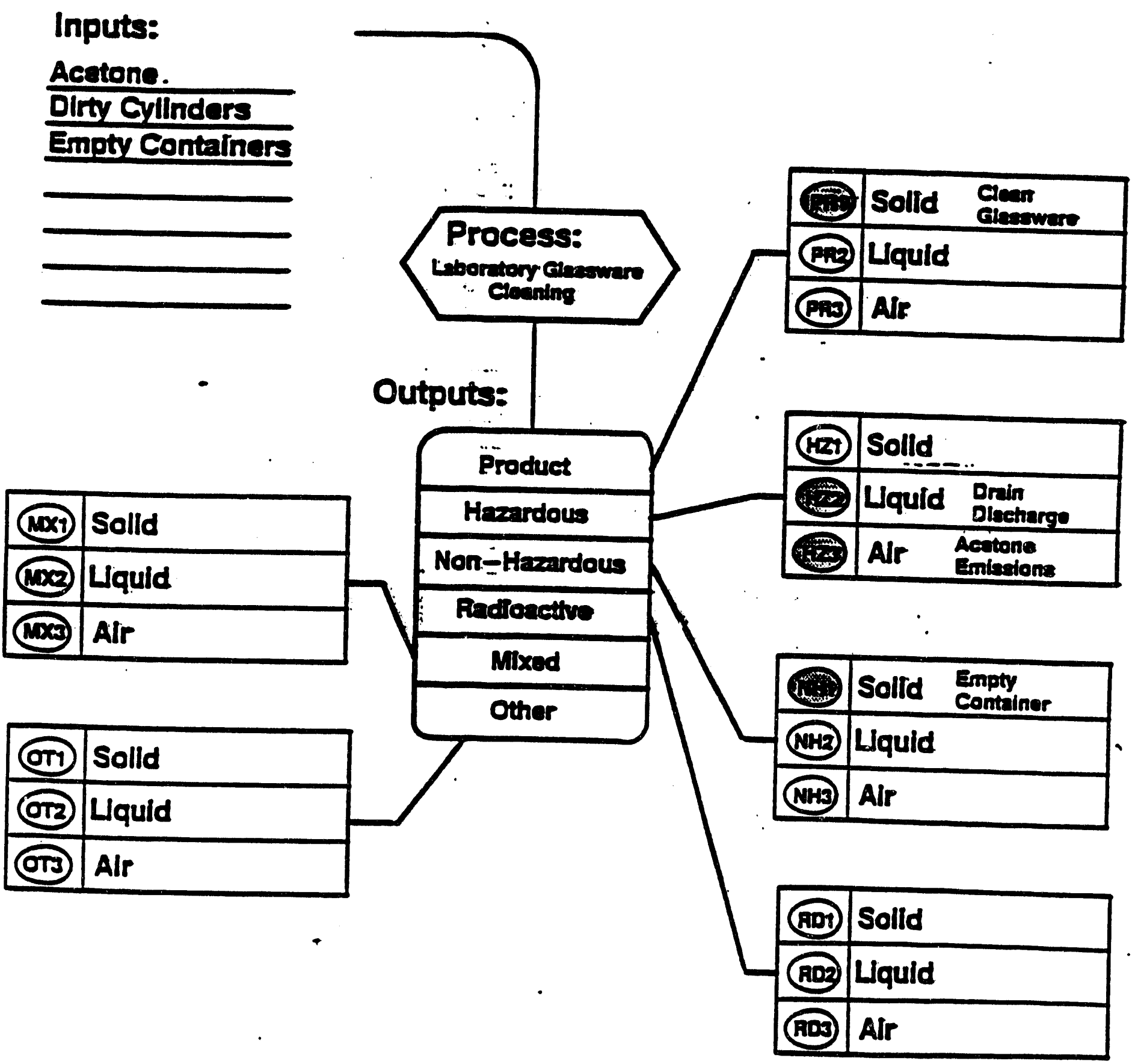




\section{Worksheet 25}

\section{Process Flow Diagram}

This worksheet provides a method to document the proceass flow diagram for the ascasumem. The flow diegram should identify all Assessment Code(s) associated with the procesas, all inpure materials, and outputs (productawastes). The flow dibgram should track moterials from the time they enter the procas boundary undl they leave. This diagram represemts a very simplietic fiow modet: a more detailed diagram may be required to identty all waste streams. espocially for complex, mult-step procieses.

1. Title or Assassmemt ID Code(s): List the PWA THte or PWA ID Code given on PPOA -1. 2 Page this workencet. : Indleate the page number for this workstieet and the number of pages for

3. Inpuras: List the input materials on the lines provided. Fill in the Process Name box. Then highilght those outputs that are applicable to the process (e.g. Proctuct, Hazardous, cte). Then sub-categortze those outputs into solld. llquid, or air emission streams by hiohlighting the corresponding output stream. A streem 10 Code is provided for each sub-extegory of waste.

4. Outputu: The Strean ID Code provides a uniform coding scheme for the ralease information. A brief waste description may be recorded in the box to the right of the Stream ID Code. The code information is summarized in the table below.

\begin{tabular}{|c|c|}
\hline \multicolumn{2}{|c|}{ esin } \\
\hline Dedionator & Code \\
\hline Product & $\overline{P R}$ \\
\hline Herendous & $\overline{H Z}$ \\
\hline Nontherardous. & MH \\
\hline Radionctive & RO \\
\hline Mbred & $\overline{n x}$ \\
\hline Other & OT \\
\hline
\end{tabular}

Solid Stream $=1$. Liquid Stream $=2$, Air Stream $=3$ 


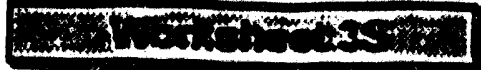

Lovel 1

Page 1 of 1

Pollution Prevention Opportunity Assessment

Material \& Waste Stream Summary

Tite: Laboratory Giasoware Cloaning

PPOA 1D Coda: CLPTO16LLABCLEAN-01

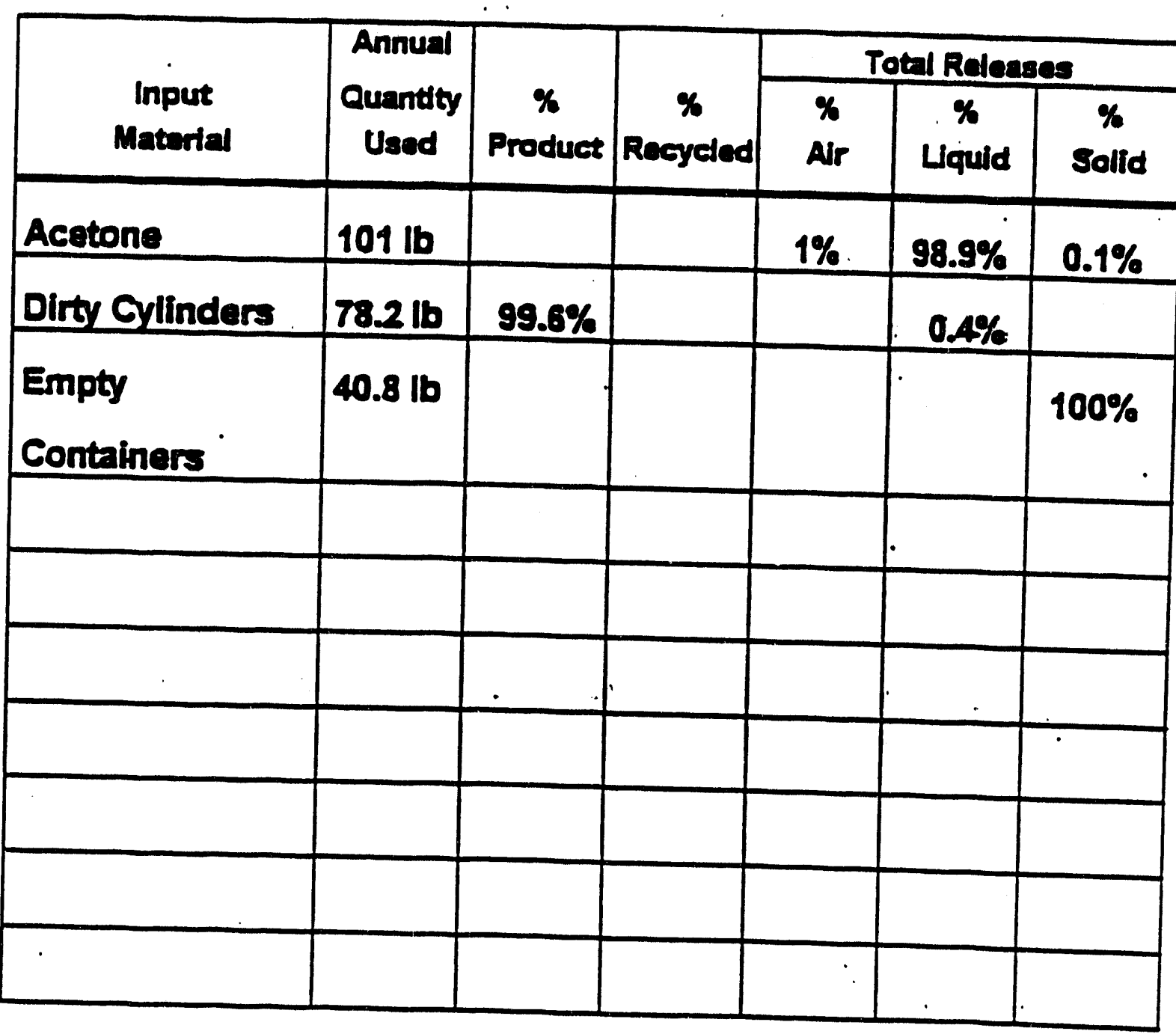

Does the process require further analysis based on the site's Priority MaterialWaste Stream List?

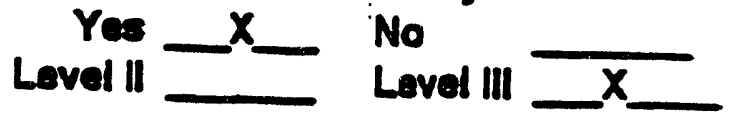




\section{Workaheot 35}

This worksheet provides a briof summary of the input materials and output streams from the operation or activity being assessed. Its purpose is to provide the pollution prevention team an overview of the waste streams reaulting from the PPOA.

1. Tite: List the PPOA title given on PPOA-1.

2. Assesesment ID Code: List the PPOA ID Code given on PPOA-1.

3. Input Material: List the material names which enter the operation.

4. Annual Quantty Uaed: Enter the annual quantity used for cact material llsted - include the unit of measure, e.g. lbs, curies, ete For input material from another process, it may be helphul to also identify the release components of those materials.

5. \% Product For each input material, estimate the percent of the annual quantity used which.goes to product.

6. \% Recycled: For each input material, estimate the percent of the annual quantity used which is recycled.

7. \% Air: For each input material, estimate the percent of the annual quantity used which is an air weste stream.

8. \% Liquid: For each input material, estimate the percent of the annual quantity used which is a liquid waste stream.

9. \% Product: For each input material, estimate the percent of the annual quantity used which is a solid waste stream.

10. Does the procasas require further analysis based on the site's Priority Material/Waste Stream List? Using your site's Priority MaterialWasto Stream List and the DOE Graded Approach Logic Diagram, determine if further assessment is necessary. If yes, indicate the level of assessment: required. 


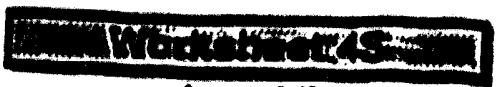

Level II

Pollution Prevention Opportunity Assessment

Option Summary

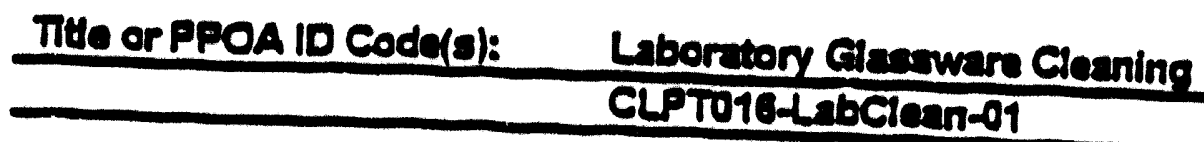

Option Na 1 .

Use a soap and water solution to clean the greduated oylinder. This will elliminate the ecetone hezand and diecharge.problema soep realdue will nead to be investgated as a potental problem.

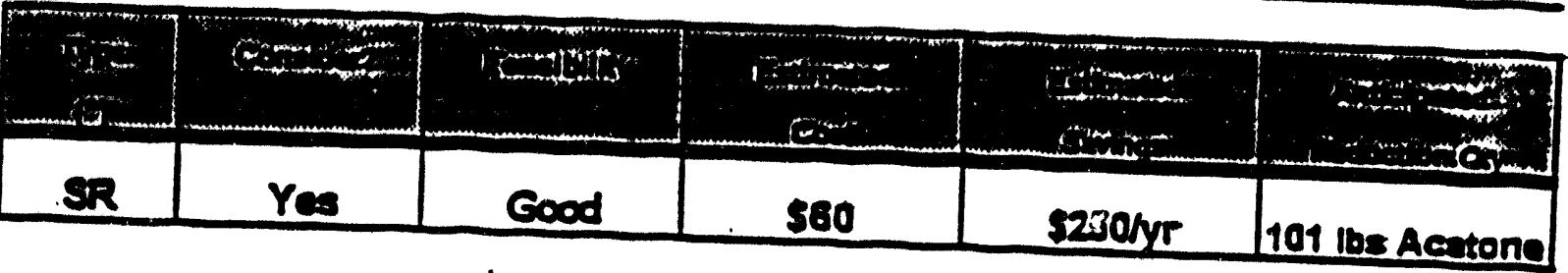

Option Na 2 .

Use leas acetone. Try to eliminate at least one of the ringes This will. reduce the amount of acetone used and discharged to the sewer and air.

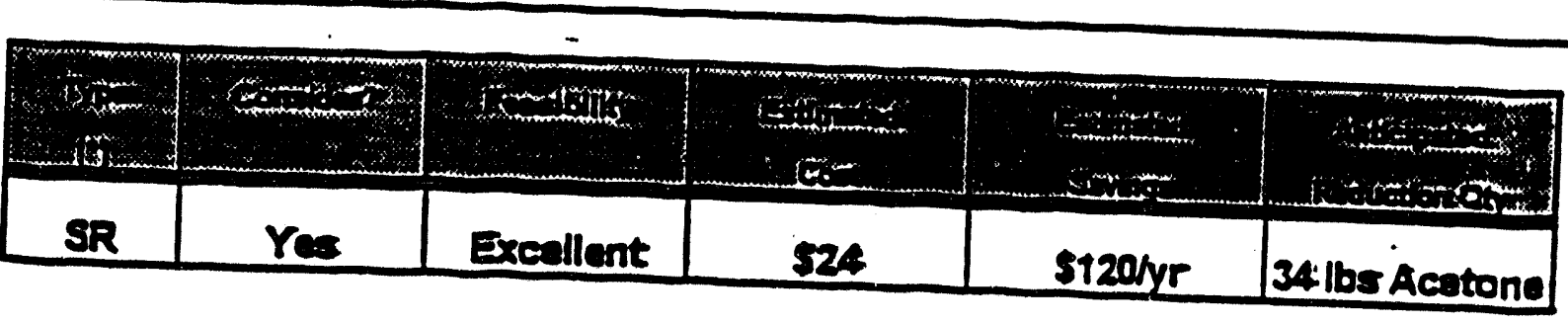

Option Na. 3 .

Don't clean the cylinder. Lot the cylinder drain out into the etch tank Then lot any residual material loft evaporate in the cylinder under a vent hood. This will eliminate acetone usage. A drawback is the potential offect of the residue left in

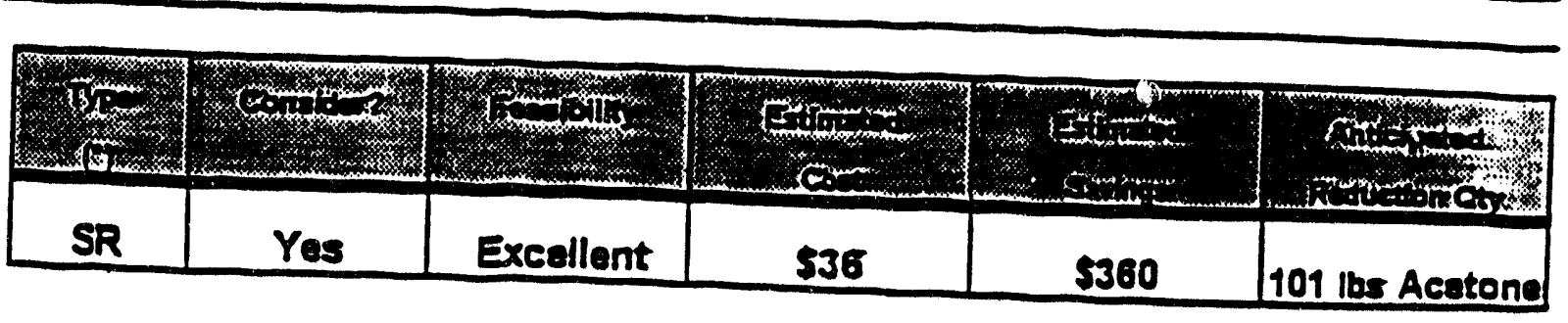

(") Type = Source Reduction, Recycling, Treatment, or Disposal 
This summary sheot serves as a method to record and evaluate the options that have been identified during brainstorming sessions or other option generating techniques.

1. THE or PPOA 10 Codo(o): List the PPOA TItle or PPOA ID Code givan on Werkaheet 19.

2. Opten : Optlons generated should be numbered consecuttively. Briefly deseribe esen option, affected materials, waste streams, upstream/downstream impacts if implemented, and anticipated roduction quantity if implementad.

3. Type: Indicate whether the option is source reduction, recycling, treatment, or disposal.

4. Consider?: If the option is worth further consideration, enter YES. If not, enter NO and briofly indieate in the Option Deseription why not.

5. Fandbillty. Frovide a brief description. (Exeallent, good, fair, poor)

6. Estimatad Cost Estimate an implementation cost.

7. Estimated Cost Savings: Estimate the cost savings.

8. Anticipatad Reduction Qty:- Estimate the weight or volume of the waste that will be reduced.

Nota: Typically, it is difiricult to estimate the anticipated waste reduction or cost avoidance in the initial phases of implementation because of many factors. However, for some options, especially in cases whore the option provides complete elimination of a hazardous material or waste stream, these estimates can be accurately completed.

The process by which options are identified should oceur in anr environment that encourages creattity and independent thinking. Brainstorming sessions are effectlve ways for individuals to generate options. To make these sessions beneficial, research is often necessary. Provided below is a fishbone diagram that will help the team generate ideas.

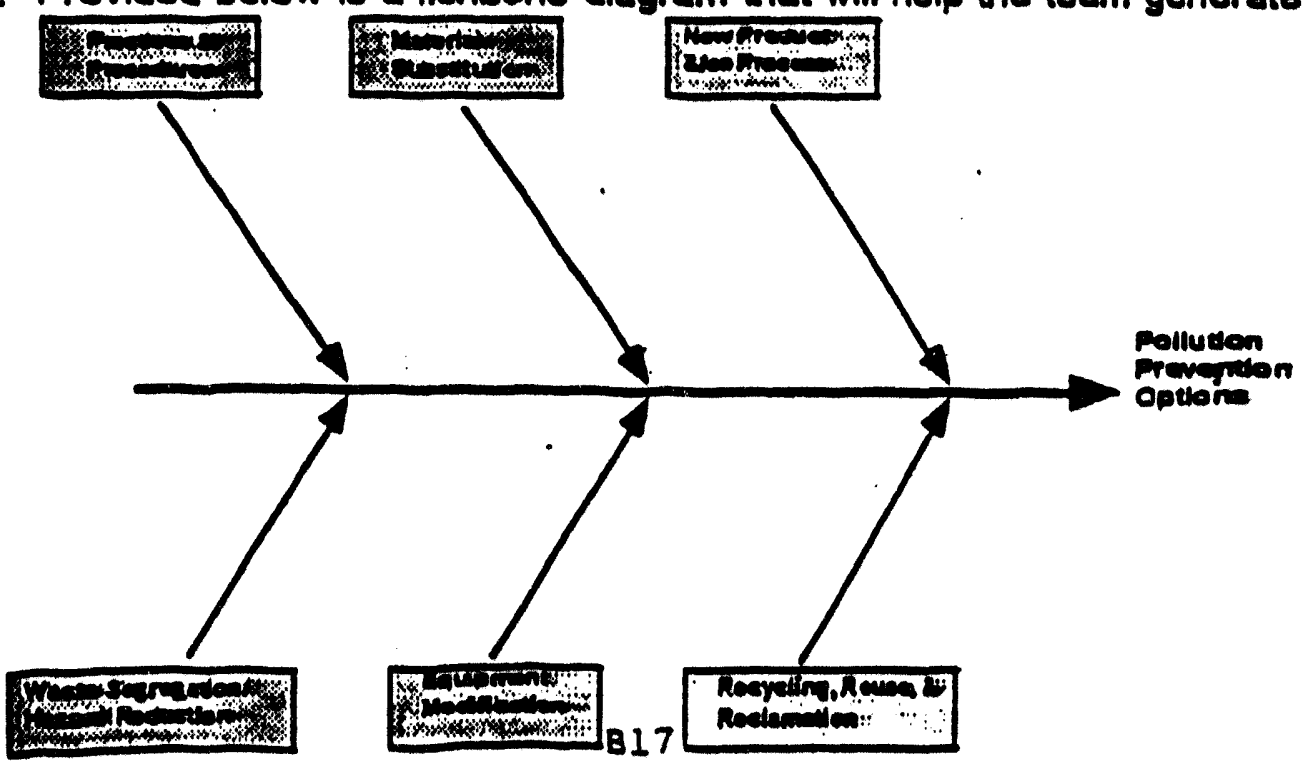




\title{
Pollution Prevention Opportunity Assessment
}

\author{
Final Summary
}

Tite: Proalo Codalo: Laboratory Gianowars Claning

CLPTOTCL SBCTOEn-1

Asseasmonte A lovel I and level II PWA wern completad on the common Iaboratory prectee of cleaning glaseware. The operetor of the process had many ldese to ellminate or minimize the wede genereted The dete for thils aseasament wes collectad by weighing a full, compty, and bone doy ovlinder to

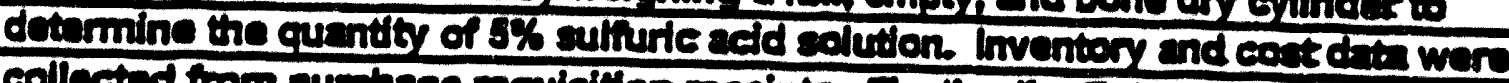
collected from purchase requilition recelpte. Finally, Jim Bob conductad an experiment to dotermine the amount of acatone that was evepording durtng the cleaning procese. Asaumptions made during this ascecament were: the sulfurle seid addidons ware taken imto scecunt in another PWA, drin discharge of acatone ls hazardous and not permitted by the POTW, no volatilisation of acotone oceurs from the empty containers, the same fiass cylinder is uesd and without loss due to breakage.

Conclusions: Jim Bob concluded that there are many options to implement that would ofther eliminate or reducs the amount of waste generated the use of acetone to clean the cylinder with sulfuric acid residue is not necesasary. Water or not deaning the cyllinder are definite options which could eliminate the acatone waste stream completaly. The following recommendations are made:

Recommendations:

Iim Bob recommends working with the other PWA team to pursue an automatic dispenser for the sulfurte additions. If the cost of this new equipment is prohibitive, then he recommends that one cyllinder be sot aside for the additions and no cleaning be done. If others are concerned with contamination, then he recommends cleaning the cyllinder with water. 
Workaheat 89

This sheat provides a brief summary of other pertinent information about the sethity being assassed. Its purpose is to document how this assasament was pertormed. the conclusions resctied by the team, and the recommendations for further actions.

1. Data: Last the date this sheet was comploted.

2 Tito: Liat the ttue given on Workaheet 15.

3. PPOA iD Code(s): Liat the 10 Code(s) giverr on Workeneet 18.

4. Asacasmente Briffly deseribe the approach (methodology) usad to complete this asseasment and any assumptions made.

c. Conclusions: Briofly describe the wate streams or input material to be minimizad, banefits achieved from this assesement, end any concerns (environmental or health risks) associated with the material or operation.

6. Recommendattons: Briefly describe any actions that should or will be taken in respect to this assosament. 
PREPARED FOR: DEPARTMENT: DATE:

SECTION B.

STIE GENERATED WASTES

1. WASTEDESCRUTIONNAME:

2MATERLAL CHARACTERISTICS: (ATTACF WASTE MATERUL PROFILE SHIEETS WTTH COMPOSTIION DATA AS NECESSARY
( ) Liaum
( ) soLn
( ) MODED PHASE

3.GENERATION RATE

(SHYW UNITS)

ESTMMATED QUANITIY:
( ) ONE-TIME ONLY
( ) CONTINUOUS
( ) DNTERMTITENT

4.WASTE ORIONSFOURCES

DESCRIBE HOW THEE WASTE IS GENERATED.

IS A SUITABLE LESS TOXIC OR HAZARDOUS SUBSTITUTE SOURCE MATERLAL AVAII_ABLE
( ) YES
( ) NO
( ) DONT KNOW

(FF YES, LIST SUTTABLE SUBSTITUTES BELOW.) 
WASTE NAVE:

S.FLNAL PACKAOLNO:

( )BULK

( )ROLL OFF BDS

( )DRUMS

( )BAGS

( )PLLES

( ) OTHER (DESCREE)

6.WASTE ORIGLNSSOURCES

IS THE WASTE A HLAZARDOUS WASTE?

( ) YES ( ) NO

IS THE WASTE A MOCED WASTE?

( ) YES ( ) NO

IS THE WASTE RADIOACTIVE?

( ) YES ( ) NO

IS THE WASTE A HLAZARDOUS MATERLAL?

( ) Yes

( ) NO

7.APPLICABLE REGULATIONS:
( ) RCRA
( ) TSCA
( ) OSELA
( ) CWA
( ) OTHER (LIST)

8.PROPOSED MANAGEMDENT:
( ) ONSITE
( ) OFFSITE

( ) COMMERCIAL TSDF

( ) ONSITE TSDF

( ) OTHER (DESCREBE)

9.APPLICABLE WASTE MINDMIZATION TECHNIQUES:
( ) MATERLAL SUBSTITUTION
( ) RECLAMATION/REUSE
( ) INVENTORY CONTROL
( ) DECONTAMDNATION
' ( ) CONSOLDATION
( ) STLE REDUCTION
( ) SEGREGATION
( ) OTHER

(ATTACH TECINICAL AND ECONOMIC EVALUATIONS FOR EACH TECHNIQUE CHECKED) 
WASTE MINIMIZATION

FEASIBIITY ASSESSIVENT

SLALMLARY
2.tCE: UF:

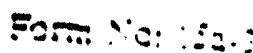

Reirsion ki:

WASTE NAME:

10.1S WASTE MLVLMLATION FEASTBLE?

( ) YES

( ) NO

IF YES, LIST TECHNIQUE(S) TO BE APPLEDD.

PREPARED BY:

WASTE MANAGEMENT RECOMMENDATION

WASTE MANAGEMENT ENGINEER

'ECOMMENDED BY:

WASTE MINIMIZATION COORDDATOR

DATE:

$b$ 

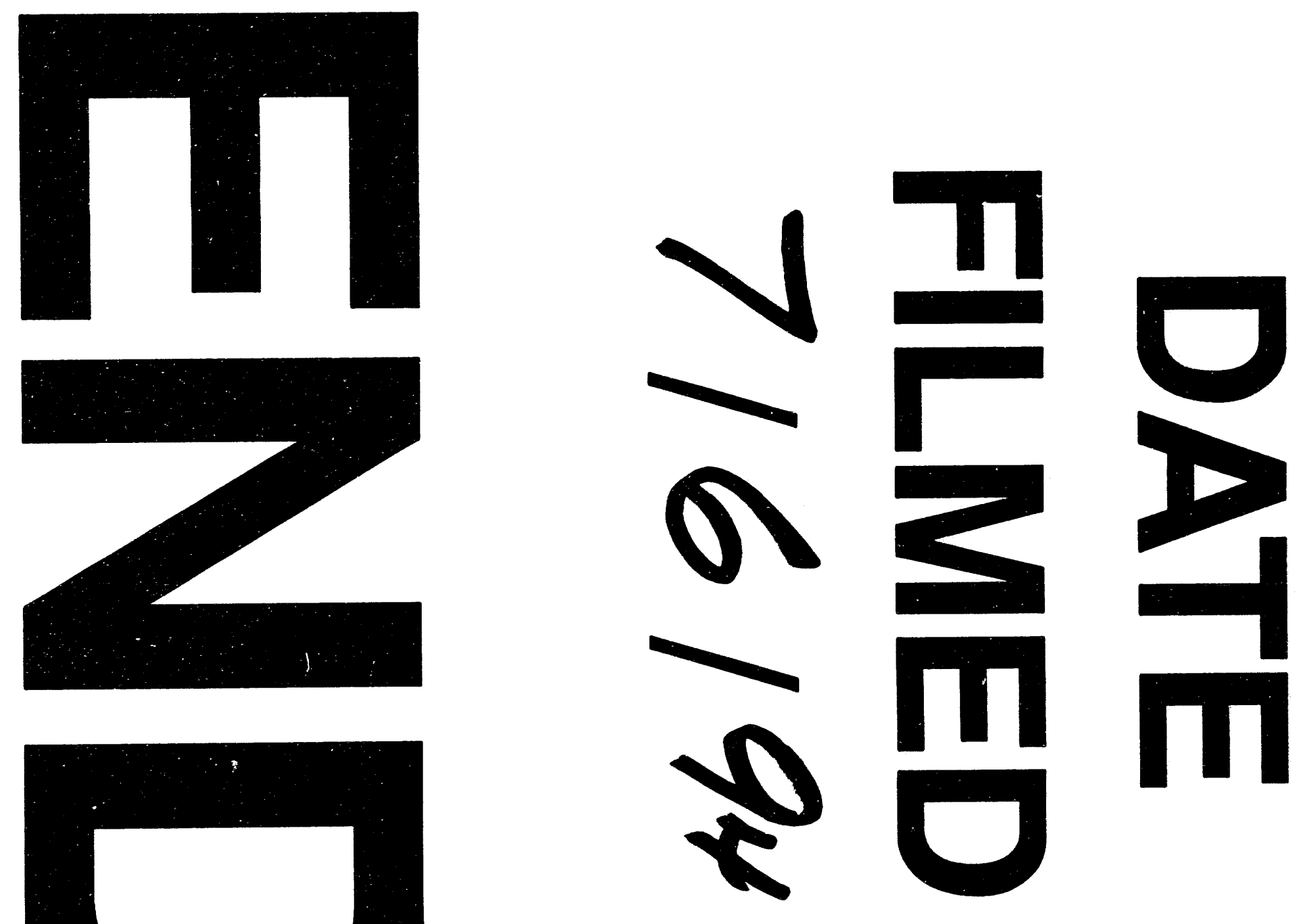

$\tau$ 


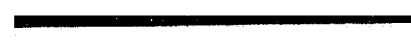

